\title{
1 Effects of acute ocean acidification on 2 spatially-diverse polar pelagic foodwebs: \\ 3 insights from on-deck microcosms
}

4 Tarling $G A_{1}$, Peck $V_{1}$, Ward $P_{1}$, Ensor $N S_{1,2}$, Achterberg $E_{3,4}$, Tynan $E_{3}$, Poulton $A_{5}$, Mitchell $E_{6}$,

5 Zubkov $\mathrm{MV}_{5}$

6 1. British Antarctic Survey, Natural Environment Research Council, High Cross, Madingley Rd, 7 Cambridge, CB3 OET, UK

8 2. Marine Scotland Science, Marine Laboratory, 375 Victoria Road, Aberdeen, AB11 9DB, UK

9 3. Ocean and Earth Science, National Oceanography Centre Southampton, University of 10 Southampton, Southampton SO14 3ZH, UK

11 4. GEOMAR Helmholtz Centre for Ocean Research, Kiel, 24148, Kiel, Germany

12 5. National Oceanography Centre, Waterfront Campus, European Way, Southampton, SO14 3ZH, UK

13 6. Scottish Association for Marine Science, Dunstaffnage Marine Laboratory, Oban, Argyll, PA37

14 1QA, UK

15 Abstract

16 The polar oceans are experiencing some of the largest levels of ocean acidification (OA) resulting

17 from the uptake of anthropogenic carbon dioxide $\left(\mathrm{CO}_{2}\right)$. Our understanding of the impacts this is having on polar marine communities is mainly derived from studies of single species in laboratory conditions, while the consequences for food web interactions remain largely unknown. This study carried out experimental manipulations of natural pelagic communities at different high latitude sites in both the northern (Nordic Seas) and southern hemispheres (Scotia and Weddell Seas). The aim of this study was to identify more generic responses and greater experimental reproducibility through implementing a series of short term ( 4 day), multilevel ( 3 treatment) carbonate chemistry manipulation experiments on unfiltered natural surface ocean communities, including grazing copepods. The experiments were successfully executed at six different sites, covering a diverse range of environmental conditions and differing plankton community compositions. The study identified the interaction between copepods and dinoflagellate cell abundance to be significantly altered by elevated levels of dissolved $\mathrm{CO}_{2}\left(p \mathrm{CO}_{2}\right)$, with dinoflagellates decreasing relative to ambient conditions across all six experiments. A similar pattern was not observed in any other major 
30 phytoplankton group. The patterns indicate that copepods show a stronger preference for

31 dinoflagellates when in elevated $p \mathrm{CO}_{2}$ conditions, demonstrating that changes in food quality and

32 altered grazing selectivity may be a major consequence of ocean acidification. The study also found

33 that transparent exopolymeric particles (TEP) generally increased when $p \mathrm{CO}_{2}$ levels were elevated,

34 but the response was dependent on the exact set of environmental conditions. Bacteria and

35 nannoplankton showed a neutral response to elevated $p \mathrm{CO}_{2}$ and there was no significant

36 relationship between changes in bacterial or nannoplankton abundance and that of TEP

37 concentrations. Overall, the study illustrated that, although some similar responses exist, these

38 contrasting high latitude surface ocean communities are likely to show different responses to the

39 onset of elevated $p \mathrm{CO}_{2}$.

40

41 Key Words: Arctic, Southern Ocean, copepod, phytoplankton, dinoflagellates, bacteria,

42 nannoplankton, transparent exopolymeric particles, $\mathrm{pCO}_{2}$ 


\section{Introduction}

44 The on-going shift in seawater carbonate chemistry and related reduction of ocean pH (termed

45 ocean acidification, $\mathrm{OA})$ caused by increasing atmospheric carbon dioxide $\left(\mathrm{CO}_{2}\right)$ levels has the

46 potential to affect a wide range of marine organisms (Fabry et al. 2009, Cooley et al. 2009). Taxa that

47 inhabit oceanic surface layers are particularly at risk since that is where the greatest changes are

48 being observed. Some taxa respond sensitively to elevated $\mathrm{CO}_{2}$ levels, whereas the response in

49 others is mixed and often highly species-specific (Engel et al. 2008, de Nooijer et al. 2009, Doney et

50 al. 2012, Beaufort et al. 2011, Whiteley 2011). Our present understanding of OA impacts is largely

51 limited to single species responses while the consequences for food web interactions remain

52 relatively unknown (Rossoll et al. 2012). For instance, the response at the community level may

53 dampen the overall impact to elevated $\mathrm{CO}_{2}$ levels through altered physiological performance, prey

54 switching and species replacement (Rossoll et al. 2013).

55 The solubility of $\mathrm{CO}_{2}$ increases with decreasing temperatures, such that polar oceans have naturally

56 higher $\mathrm{CO}_{2}$ and correspondingly lower carbonate ion concentrations (Sabine et al. 2004). With a low

57 buffer capacity and a relatively low starting baseline, polar oceans are particularly susceptible to

58 ocean acidification and are expected to be the first to experience carbonate mineral undersaturation

59 and large decreases in pH (McNeil and Matear 2008, Steinacher et al., 2009). As a result, the polar

60 regions, and particularly the Arctic, have been a focus for studies into the effects of projected OA on

61 the marine environment (Riebesell et al. 2013).

62 Most studies of the effect of OA on pelagic organisms have involved laboratory and mesocosm

63 experiments. Laboratory monoculture experiments allow experimental conditions to be tightly

64 controlled and are valuable at identifying possible mechanisms and impacts. However, the outcomes

65 of these experiments cannot be fully realistic because species are studied in isolation from the

66 natural ecosystem in which there may be shifts from more $\mathrm{pH}$-sensitive to more $\mathrm{pH}$-tolerant species. 
67 Furthermore, the experimental conditions themselves (e.g. nutrient levels) may not be representative of typical oceanic conditions. Some of these shortcomings are overcome in carrying out mesocosm experiments, where large volumes $\left(50\right.$ to $75 \mathrm{~m}^{3}$ ) of natural planktonic communities are incubated in situ and manipulated with regards artificially altering $\mathrm{pH}$, carbonate chemistry and nutrient levels (Riebesell et al. 2010). The logistical demands of such operations have, nevertheless, restricted their deployment to inshore regions which may not adequately cover the range of conditions and communities found in the open ocean.

To date, the main approach to considering planktonic community responses to OA in open-ocean environments has been through short-term ( 1 to $14 \mathrm{~d}$ ) incubations of natural communities on scientific vessels using on-deck microcosms (1 to 50 L; Riebesell et al. 2000, Tortell et al. 2002, Hutchins et al. 2007, Richier et al. 2014). Although the incubation volumes are relatively small compared to mesocosms, this approach does allow identical experiments to be repeated across natural gradients in carbonate chemistry, temperature and nutrients. The approach has the advantage of examining a range of natural communities adapted to their particular environmental ranges. Comparisons can be made on how each community responds to the same stressor (i.e. changes in carbonate chemistry). The disadvantage of this approach is in the sudden induced change in $\mathrm{pH}$ and carbonate chemistry to which the community is given little time to adapt. Nevertheless, alternative longer-term, multigenerational approaches (Cripps et al. 2014) are best suited to studies of single species, and over timescales that are unfeasible for spatially extensive, vessel-based research. We used the short-term on-deck microcosm approach to consider the response of planktonic foodwebs, from a range of polar and sub-polar environments, to acute OA perturbations.

OA may affect food-webs in a number of ways, each with their own feedbacks to other parts of the system. Short-term acute-change experiments of this sort cannot characterise all such changes. However, in performing identical experiments across a range of environmental starting conditions, they can identify where there are common responses to acute change, or otherwise, how responses 
92 vary according to the initial environmental conditions and community composition. In particular, we

93 investigate two separate, but not mutually exclusive, hypotheses:

94 i) that acute OA change will lead to the accumulation of transparent exopolymeric particles (TEP)

95 which will stimulate the microbial food web;

96 ii) that acute $O A$ change will alter the nutritional quality of individual phytoplankton species and

97 lead to a change in zooplankton grazing preferences, so altering phytoplankton community

98 composition and potentially zooplankton body condition.

i) Stimulation of TEP production TEP are gel-like particles that form through coagulation of the polysaccharide fraction of dissolved organic matter (Passow, 2002). It has been proposed that increasing levels of $p \mathrm{CO}_{2}$ in the surface ocean leads to more partitioning of the organic carbon fixed by marine primary production into the dissolved rather than the particulate fraction. This enhances the accumulation of dissolved organic carbon (DOC) in the surface ocean, and the concurrent accumulation of TEP. Such an accumulation was first noted by Engel (2002) in on-board experiments under increased $p \mathrm{CO}_{2}$, although whether the accumulation was due to increased production or modification of TEP structure remains uncertain (Weinbauer et al. 2011). Enhanced TEP has also been associated with nutrient stress (Engel 2002, Engel et al. 2004, Bellerby et al. 2008). Increased TEP aggregation can result in higher abundances and production of bacteria by attracting cells to a microbial hotspot (Simon et al. 2002). Nevertheless, contrasting relationships between TEP and bacteria have been found across diverse ocean areas (Corzo et al. 2005, Passow et al. 2001, Hung et al. 2003, Santschi et al. 2003, Passow and Alldredge 1994, Baskar and Bhosle 2006). We investigated

112 if TEP production is affected by acute $\mathrm{pH}$ change and whether there is evidence of an enhancement 113 of the microbial community as a result. Furthermore, we also considered whether any such patterns 114 are altered by an additional trophic level (i.e. copepod grazers), given that copepods can directly 115 feed on clusters of TEP (Passow and Alldredge 1999, Ling and Alldredge 2003). 
ii) Changes to grazing preferences There is growing evidence that enhanced $p \mathrm{CO}_{2}$ levels alter the nutritional quality of individual phytoplankton species available to grazers via species specific changes in their biochemistry (Riebesell and Tortell 2011). One major factor is taxonomic differences in the kinetic properties of carbon acquisition. Diatoms, for instance, have a much higher enzymatic specificity for carbon than dinoflagellates (Tortell 2000), which affects the rate of carbon enrichment per unit $p \mathrm{CO}_{2} . p \mathrm{CO}_{2}$ increase may also alter carbohydrate and fatty acid content in certain phytoplankton (Wynn-Edwards et al. 2014). Zooplankton have specific stoichiometric dietary requirements (Nobili et al. 2013) and an ability to select the prey species that suit their overall needs (Kleppel 1993). Therefore, this study will consider how zooplankton grazing preferences may alter between different acute OA treatments, and whether zooplankton body condition is affected.

We conducted short-term bioassay $\mathrm{CO}_{2}$ perturbation experiments using natural seawater collected from the surface ocean and brought into a controlled laboratory on the deck of the research ship. This natural unfiltered seawater was manipulated to raise $p \mathrm{CO}_{2}$ to future predicted levels, if at an acute rate. Locally-caught herbivorous copepods were subsequently introduced into certain incubation chambers to simulate natural food-web scenarios. The procedure was repeated in a number of Arctic and Southern Ocean oceanic settings, with contrasting environmental characteristics. In so doing, the study examines both short-term physiological responses, through acute exposure to raised $p \mathrm{CO}_{2}$ levels, alongside adaptive community variability, given that the communities being incubated were extracted directly from their natural setting. This means that responses will be dependent on initial community structure alongside community changes resulting from competition between the multiple genotypes present within the incubation. Overall, this study examines the effects of acute changes to $\mathrm{CO}_{2}$ levels on real-world planktonic food-webs found in both polar oceans. 


\section{Methods}

140

141

145

\subsection{Sampling stations}

This study was undertaken using on-board incubations of unfiltered seawater with and without additions of net-caught zooplankton as part of two open-ocean research campaigns. The research cruises were carried out on board RRS James Clark Ross in June-July 2012 in the sub-Arctic and Arctic Ocean (Cruise JR271) and January to February 2013 in the Southern Ocean (Cruise JR274). As part of these cruises, successful experimental incubations were performed in a total of six high-latitude environments (Table 1 ) with a diverse set of starting conditions. Two of the incubations were performed in Arctic waters, one in the open Greenland Sea (E03 271) and the other at the Greenland sea-ice margin (E04 271). A further two incubations were performed in the Southern Ocean, the first towards its northern limits close to South Georgia (E03 274), and the other, further south in the Weddell Sea, close to the South Sandwich Islands (E04 274). The remaining two incubations were carried out outside of true polar waters, one in the North Sea (E01 271) and the other in the subArctic Barents Sea (E05 271).

\subsection{Water collection}

The incubations were set up with unfiltered seawater taken from the upper-mixed layer at the station location. On the day of the experimental setup, vertical CTD profiles were performed to characterise water column variables (temperature, salinity, chlorophyll fluorescence) and determine water column structure. The depth of water collection for the experimental setup was then decided upon based on these initial profiles and was typically from the middle of the upper mixed layer. The unfiltered water was collected from dedicated CTD casts using a titanium frame CTD and acidcleaned 24 x 10 L Rosette OTE (Ocean Test Equipment) bottles. On deck, the bottles were immediately transferred to a class-100 filtered air environment within a trace-metal clean container to avoid contamination. The unfiltered water was transferred using acid-cleaned silicon tubing to $1 \mathrm{~L}$ 
acid-cleaned clear Duran bottles and the bottles checked for any extraneous copepods, which were

removed before the bottles were sealed, pending carbonate chemistry manipulation and the addition of hand-picked live copepods from net-catches (see below). Subsamples were collected simultaneously for time-zero (TO) measurements of each of the variables to be measured over the subsequent time course (Table 2).

Further subsamples at time zero (TO) were taken directly from the CTD and immediately measured for total alkalinity (TA) and dissolved inorganic carbon (DIC) to characterise the carbonate chemistry system in seawater; details for the analytical methods can be found below. The remaining variables of the carbonate system were calculated with the CO2SYS programme (version 1.05, Lewis and Wallace, 1998; van Heuven et al., 2011), using the constants of Mehrbach et al. (1973) refitted by

173 Dickson and Millero (1987). Carbonate chemistry in the experimental bottles was subsequently 174 manipulated using equimolar additions of strong acid $\left(\mathrm{HCl}, 1 \mathrm{~mol} \mathrm{~L}^{-1}\right)$ and $\mathrm{HCO}_{3}^{-}\left(1 \mathrm{~mol} \mathrm{~L}^{-1}\right)$, as recommended by Gattuso et al. (2010) for increasing DIC at constant TA. The volumes of $\mathrm{HCl}$ and

$176 \mathrm{HCO}^{-3}$ required to adjust $\mathrm{pCO}_{2}$ to the chosen target values (750 and $1000 \mu$ atm) were calculated from the measured ambient state of the carbonate system in seawater using CO2SYS.

\subsection{Zooplankton collection}

Immediately after the collection of water, a motion-compensated Bongo net $(61 \mathrm{~cm}$ diameter, 100 $\mu \mathrm{m}$ and $200 \mu \mathrm{m}$ mesh) was deployed between 0 and $200 \mathrm{~m}$ to capture live zooplankton. Subsamples of the net catches were immediately analysed to determine the approximate species composition and decide on the most appropriate calanoid species (and developmental stage) to use for the incubation experiments. The choice of species varied between experimental stations, with Calanus finmarchicus being used in the North Sea (E01 271), C. hyperboreus in the Arctic (E03 271 and E04 271) and Calanoides acutus in the Southern Ocean (E03 274 and E04 274). The exact species identity of the calanoid used in the Barents Sea was unclear and classified as Calanus finmarchicus/glacialis. The chosen developmental stage was mainly copepodite stage V (CV), 
although, in E04 274, it was necessary to combine this stage with females because numbers were relatively low. Individual copepods were picked out from sub-samples analysed under a light microscope using titanium forceps (to minimise iron contamination) and acid washed pipettes and transferred to $10 \mathrm{~mL}$ glass vials containing filtered seawater and maintained at ambient sea-surface temperature. Each glass vial contained either 5 or 10 specimens, the number differing between stations to account for individual specimen size and in situ concentrations. A total of 18 glass vials were populated with copepods in readiness for their subsequent introduction into the incubation experimental bottles.

\subsection{Set-up and running of experiments}

In the trace-metal clean container, the $1 \mathrm{~L}$ Duran bottles containing the unfiltered sea-water were modified with varying aliquots of equimolar $\mathrm{HCl}$ and $\mathrm{HCO}_{3}{ }^{-}$to achieve nominal $p \mathrm{CO}_{2}$ levels of either $750 \mu$ atm or $1000 \mu$ atm. Eight individual Duran bottles per $p \mathrm{CO}_{2}$ level were prepared, while a further ten Duran bottles were left unmodified. This number allowed for two sets of triplicate bottles containing copepods in ambient conditions, $750 \mu$ atm $p \mathrm{CO}_{2}$ and $1000 \mu \mathrm{atm} p \mathrm{CO}_{2}$, as well as two sets of single bottles without copepods for each $p \mathrm{CO}_{2}$ treatment and two sets of double bottles without copepods in ambient conditions. Accordingly, the copepods in the glass vials were gently poured into six of the eight modified bottles for each $p \mathrm{CO}_{2}$ treatment, and six of the ten unmodified bottles. Each of the bottles was topped up to the rim and the lids sealed. The 26 bottles (i.e. 2 identical sets of 13 bottles) were placed on 3 plankton wheels within a controlled temperature container and maintained at ambient surface-water temperature (Fig. 2). Irradiance $\left(100 \mu \mathrm{mol} \mathrm{m} \mathrm{m}^{-2}\right)$ was provided by daylight simulation LED panels (Powerpax, UK) over a $24 \mathrm{~h}$ light cycle which approximated the ambient photoperiod and light intensity at $5 \mathrm{~m}$ (Richier et al. 2014).

The first set of 13 bottles was removed from the plankton wheels after $24 \mathrm{~h}$ and inspected to determine if there were any dead copepods in the incubation. The bottles were then immediately 
213 subsampled for the concentration of nutrients (including ammonium), TA and DIC and transparent

214 exopolymeric particles (TEP) as well as the abundance of bacteria, nannoplankton, and major

215 phytoplankton taxa. It was not possible to make all measurements on all bottles because of the

216 volumes required for each analytical method. However, each measurement was made on at least

217 one bottle with copepods and one without copepods at the three different $p \mathrm{CO}_{2}$ levels (ambient,

$218750 \mu \mathrm{atm}$ and $1000 \mu \mathrm{atm})$. The copepods were filtered out of the remaining water, rinsed in

219 deionised water (Milli-Q, Millipore) and snap-frozen in liquid nitrogen for subsequent elemental

220 composition analysis.

221 The remaining set of 13 bottles were checked for copepod mortalities at 48,72 and $96 \mathrm{~h}$ after the

222 start of the incubation. At the $96 \mathrm{~h}$ timepoint, the take-down procedure was repeated, with the

223 exception that samples for bacteria, nannoplankton and phytoplankton abundance were not taken,

224 given that they would most likely be subject to exponential growth and overgrazing effects

225 respectively after this length of time in volumes of $1 \mathrm{~L}$.

\subsection{Measurements of biological and chemical variables}

227 Nutrients Samples for macronutrients (nitrate $\left(\mathrm{NO}_{3}^{-}\right)+$nitrite $\left(\mathrm{NO}_{2}^{-}\right)$), silicic acid (dSi) and phosphate

$228\left(\mathrm{PO}_{3}{ }^{-}\right)$were collected directly from the incubation bottles into a $25 \mathrm{~mL}$ polystyrene container and stored at $4^{\circ} \mathrm{C}$ pending analysis within $12 \mathrm{~h}$. The samples were run on a Skalar San+Segmented Flow Autoanalyzer using colorimetric techniques (Kirkwood, 1996) with the exception that the flow rate of the sample through the phosphate channel was increased to improve reproducibility and peak 232 shape.

233 For ammonium analysis, $10 \mathrm{~mL}$ samples were collected in polypropylene vials and reagent added,

234 following Kerouel and Aminot (1997). Fluorometric analysis was performed $24 \mathrm{~h}$ after the addition of 235 reagent. Concentrations were estimated to an accuracy of nannomoles $\mathrm{L}^{-1}$. 
Carbonate chemistry Samples for dissolved inorganic carbon (DIC) and total alkalinity (TA) were

collected from the incubation bottles in $250 \mathrm{~mL}$ borosilicate glass bottles. TA and DIC measurements were performed using either a VINDTA 3C system (Marianda, Germany), an Apollo SciTech DIC analyser (AS-C3) or an Apollo SciTech Alkalinity Titrator (AS-ALK2), depending on availability of the instruments during the cruises. On the VINDTA 3C system, DIC was measured by coulometric titration and TA by potentiometric titration and calculated using a modified Gran plot approach (Bradshaw et al., 1981). The Apollo uses a $\mathrm{CO}_{2}$ infrared detector (LICOR 7000) to measure DIC and an open cell titration to measure TA. We have routinely used the different instruments in our lab and have found no systematic differences between them, therefore the data is inter-comparable with no significant difference between the methods. Certified Reference Materials (CRMs) (A.G. Dickson, Scripps Institution of Oceanography, batch 117 in the Arctic, batches 119 and 120 in the Southern Ocean) were used at the beginning, middle and end of each run on all instruments as a control for both DIC and TA. Precision was taken as the standard deviation of repeated analysis of CRMs. For the VINDTA $3 C$ instrument, this was $\pm 2 \mu \mathrm{mol} \mathrm{kg}^{-1}$ for TA and $\pm 3 \mu \mathrm{mol} \mathrm{kg}{ }^{-1}$ for DIC. For the Apollo instrument, TA was $\pm 1.5 \mu \mathrm{mol} \mathrm{kg}{ }^{-1}$ and DIC $\pm 3 \mu \mathrm{mol} \mathrm{kg}{ }^{-1}$. The remaining variables of the carbonate system were calculated with the CO2SYS program (MATLAB version 1.1; Lewis and Wallace, 1998; van Heuven et al., 2011) using the carbonate equilibrium constants of Mehrbach et al. (1973) refitted by Dickson and Millero (1987), the boric acid dissociation constants of Dickson (1990) and the ratio of total boron to salinity recommended by Lee et al. (2010).

TEP Samples of TEP were collected by filtration of $200 \mathrm{~mL}$ of seawater through $25 \mathrm{~mm}$ diameter polycarbonate filters ( $0.45 \mu \mathrm{m}$ pore-size, Sterlitech) at constant vacuum (200 mBar). Three separate filtrations were carried out on each $1 \mathrm{~L}$ bottle that was analysed. The particles retained on the filters were stained with $500 \mu \mathrm{L}$ of $0.02 \%$ aqueous solution of Alcian blue in $0.06 \%$ acetic acid (pH 2.5). The dye was pre-filtered using a polycarbonate filter ( $0.2 \mu \mathrm{m}$ pore-size; Sterlitech) before use. Stained filters were rinsed once with deionised water (Milli-Q, Millipore) and then transferred into $15 \mathrm{~mL}$ polypropylene centrifuge tubes (Fisher Scientific) and stored at $-20^{\circ} \mathrm{C}$. Onshore, the amount of 
262 Alcian Blue adsorbed onto the filters was determined following a soak in $6 \mathrm{~mL}$ of $80 \%$ sulphuric acid

263 for $2 \mathrm{~h}$ and determination of the absorbance of the resulting solution at $787 \mathrm{~nm}$ (absorption

264 maximum) using a spectrophotometer (U-1800, Hitachi). The amount of Alcian blue in the solution

265 was directly related to the weight of the polysaccharide that was retained on the filter (Passow and

266 Alldredge, 1995).

Bacteria and nannoplankton For each sample, $1.6 \mathrm{~mL}$ of seawater was removed and placed into a 2

$\mathrm{mL}$ polypropylene screw cap vial containing $80 \mu \mathrm{L}$ of paraformaldehyde (PFA, $1 \%$ final

concentration). The vials were then placed in a fridge and left for no longer than 12 hours before

being analysed by flow cytometry ( BD FACSort instrument) to enumerate bacterioplankton and

protist abundance (Marie et al. 1997, Zubkov et al. 2007). Samples were stained with SYBR green I

nucleic acid dye for a minimum of 30 minutes, before being analysed. Samples were run at a low

273 flow rate of $0.02 \mathrm{~mL} \mathrm{~min}^{-1}$ for 1 minute to determine bacterioplankton concentration and at a flow

274 rate of $0.2 \mathrm{~mL} \mathrm{~min}^{-1}$ for 3 minutes to determine concentrations of phototrophic and heterotrophic

protists. For each sample, a known volume of bead solution was added as an internal standard. The

bead solution consisted of Fluoresbrite multicolour $0.5 \mu \mathrm{m}$ and $1.0 \mu \mathrm{m}$ beads dispersed in $400 \mathrm{~mL}$ of

sterile Milli-Q (Millipore) water. The bead concentration was calculated before use using the FACS

calibur flow cytometer and a syringe pump (Zubkov and Burkhill 2006).

Phytoplankton composition and abundance $100 \mathrm{~mL}$ of seawater was taken from the incubation

bottles and immediately preserved in a $2 \%$ final concentration of acidic Lugol's solution stored in 250

$\mathrm{mL}$ amber glass bottles. Phytoplankton $(>10 \mu \mathrm{m})$ was identified and enumerated in $50 \mathrm{~mL}$ Hydro-Bios settling chambers on a SP-95-I inverted microscope, following Poulton et al. (2007).

Elemental analysis of copepods Total carbon, hydrogen and nitrogen of either single copepods or 
287 nitrogen and maintained at $-80^{\circ} \mathrm{C}$ for analysis on-shore. On-shore, the capsules were dried overnight

288 at $50^{\circ} \mathrm{C}$ and then combusted at $1800^{\circ} \mathrm{C}$ in the Elemental Analyser to determine total carbon,

289 hydrogen and nitrogen through analysis of the products of combustion by gas chromatography.

290 Elemental analysis of copepods from experiment E01 271 was not performed because of a

291 processing error.

\section{$292 \quad 2.6$ Statistical treatment}

Differences between $p \mathrm{CO}_{2}$ treatments (treatment effects) were analysed using a 1-way ANOVA

provided that they first passed tests for normality (Kolmogorov-Smirnov test) and equal variance

ranks. Paired t-tests were used to determine the impact of the addition of copepods to incubations,

297 subject to the same tests for normality and equal variance. Attempts to fit linear regressions were

298 made to the relationship between the relative changes in TEP and either bacteria or nannoplankton,

299 using the Sigmaplot 12.5 package (Sysstat Software Inc.) using a least-squared fitting method. Fits

300 where the slope of the curve were not significantly different from 0 were otherwise considered as

301 trends of which the consistency was compared between treatments. The influence of copepods on

302 the abundance of bacteria or nannoplankton was assessed through comparison of $95 \%$ confidence

303 intervals between incubations with- and without copepods (Zar 1996). 


\section{Results}

305

\subsection{Starting conditions}

Physical conditions Experiments at 4 of the 6 stations were carried out under true polar conditions where surface mixed-layer temperatures were between $2.2^{\circ} \mathrm{C}$ and $-1.6^{\circ} \mathrm{C}$ (E03 271, E04 271, E03 274 and E04 274). Experiment E05 271 was initiated in the sub-Arctic Barents Sea, with surface mixedlayer temperatures at around $6.5^{\circ} \mathrm{C}$. Experiment E01 271 was sited in the North Sea, where the temperature was $10.7^{\circ} \mathrm{C}$ (Table 2 ). Nutrient concentrations varied considerably, with phosphate and nitrate being at non-limiting concentrations in both of the Southern Ocean stations (E03 274 and E04 274 ) in contrast to the very low levels observed at the North Sea station (E01 271). This is reflected in the N:P atomic ratio, which was close to the Redfield ratio of 16 in the Southern Ocean, but as low as 0.6 in the North Sea. The Arctic and sub-Arctic stations showed varying degrees of nutrient limitation. Silicate was also abundant in the Southern Ocean stations compared to the other stations, with the lowest concentrations being observed in the North Sea and Barents Sea. pH was lowest at the South Georgia Southern Ocean station (E03 274) at 8.050, with a corresponding $p \mathrm{CO}_{2}$ level of $384 \mu \mathrm{atm}$. All other stations had $\mathrm{pH}$ values ranging between 8.1 and 8.2 and $p \mathrm{CO}_{2}$ levels in the region of $300 \mu$ atm.

Biological conditions Chl-a concentrations in the mixed layer reached as high as $4.2 \mu \mathrm{L} \mathrm{L}^{-1}$ at the Weddell Sea station (E04 271), and $3.03 \mu \mathrm{g} \mathrm{L}^{-1}$ at the Greenland sea-ice margin station (E04 271) but only $0.31 \mu \mathrm{g} \mathrm{L}^{-1}$ in the North Sea (E01 271). There appeared to be little correspondence between levels of Chl-a and TEP across stations, with relatively high TEP levels occurring at stations where Chla was both low (E01 271) and moderately high (E05 271). TEP concentrations were comparatively low in both Southern Ocean stations (E03 274, E04 274). The highest abundance of bacteria was observed in the open Greenland Sea (E03 271) and the Barents Sea (E05 271), at above 1 million cells $\mathrm{mL}^{-1}$, while the Greenland sea-ice margin station (E04 271) contained the lowest numbers, at less 
than half of those levels of abundance. Nannoplankton abundance similarly was highest at stations E03 271 and E05 271, and were almost an order of magnitude lower at the Weddell Sea station (E04 274).

The phytoplankton community analysed from the Lugol's samples was numerically dominated by diatoms at stations in the North Sea (E01 271), the Greenland sea-ice margin station (E04 271) and in the Weddell Sea (E04 274, Fig. 2). Dinoflagellates were the dominant taxa in the Barents Sea (E05 271) while there was more of an even mix of phytoplankton taxa in the open Greenland Sea (E03 271) and near South Georgia (E03 274). Those stations dominated by diatoms had relatively high cell counts, while cell counts were low where dinoflagellates made up a large fraction of the phytoplankton community.

The choice of calanoid species for the incubations differed between stations, based on their relative availability in net-catch samples (Table 1). There was as much variability in the $\mathrm{C}: \mathrm{N}$ mass ratio within as between species, indicating that body condition varied according to locality (Table 3, Fig. 2). Higher $\mathrm{C}: \mathrm{N}$ mass ratios are considered to reflect better body condition in that such individuals contain greater amount of body reserves. Calanus hyperboreus CV in the open Greenland Sea (E03 271) had a median C:N mass ratio that was almost $30 \%$ higher than the same species and stage found at the Greenland sea-ice margin (E04 274). Similarly, Calanoides acutus (CV and female combined) in the Weddell Sea had C:N mass ratios that were at least double of those collected at South Georgia (CV only, E03 274). Therefore, the physiological states of the populations chosen as grazers in each set of incubations were diverse, reflecting different life-history and feeding trajectories up to the point of capture.

\subsection{Outcome of manipulations on water chemistry}

The influence of the equimolar additions of acid and base on nutrient and silicic acid levels and the carbonate chemistry is fully detailed in Appendices 1,2 and 3. The manipulations were successful in 
increasing DIC levels whilst maintaining relatively constant levels of TA. However, in some instances,

353 the $p \mathrm{CO}_{2}$ target levels were not attained, with the measured levels of $p \mathrm{CO}_{2}$ after the manipulations

354 being below those intended. The effects of the additions on nutrient and silicic acid concentrations

355 was negligible given the minute volumes that were added.

\subsection{Response of TEP and the microbial community}

TEP response After 96 hours, TEP concentrations increased in all of the control (ambient conditions, no copepods) incubations across all six sets of experiments (bottle effects, Table 4). The rate of increase varied between experiments, with the highest rate observed at the Barents Sea station (E05 $271,5.71 \mu \mathrm{g}$ xanthan equivalent $\mathrm{L}^{-1} \mathrm{~h}^{-1}$ ) where the corresponding $\mathrm{N}: \mathrm{P}$ atomic ratio was relatively low (5.5). The lowest rates occurred in the Southern Ocean stations (E03 274, E04 274, 0.1 to $0.4 \mu \mathrm{g}$ xanthan equivalent $\mathrm{L}^{-1} \mathrm{~h}^{-1}$ ), where $\mathrm{N}: \mathrm{P}$ was close to the Redfield ratio of 16 (Redfield 1958).

Relative to this tendency for TEP accumulation over time, the only experiment to show an increase above that otherwise expected after $24 \mathrm{~h}$ was E04 274 for the $1000 \mu$ atm treatment (treatment effects, Table 4). However, by 96 h, significant increases were also found in E01 271, E04 271 and E05 271. Only experiments E01 271 and E04 274 showed significant increases in both the $750 \mu$ atm and $1000 \mu \mathrm{atm}$ treatments after $96 \mathrm{~h}$, the others being limited to significant increases in the 1000 $\mu$ atm treatments only.

The effects of the presence of copepods on TEP were mixed (copepod effects, Table 4). None of the experiments showed any significant increase or decrease in TEP above background increases by 24 h. By 96 h, four of the six experiments showed significant increases in TEP (E01 271, E03 271, E05

372271 and E03 274), while one experiment showed a significant decrease (E04 271) and one no 373 significant change (E04 274).

374 Bacterial response Compared to the variance in bacterial cell counts for the starting conditions (T0 375 samples), there was no significant change in the abundance of bacteria after $24 \mathrm{~h}$ either at ambient 
conditions or in the two $\mathrm{pCO}_{2}$ treatments (Fig. 3). The presence or absence of copepods in the incubations had a significant impact on bacterial abundance in certain instances. In ambient conditions in E04 271 and in the $750 \mu$ atm treatment in E04 274, the presence of copepods significantly reduced the number of bacterial cells. However, bacterial numbers were significantly enhanced by the presence of copepods in the 1000 ratm treatments in experiments E05 271 and E03 274. For the majority of experiments however, the presence or absence of copepods had very little impact on bacterial numbers under ambient or increased $p \mathrm{CO}_{2}$ levels.

Nannoplankton response There was similarly little pattern in the response of the nannoplankton community to incubation conditions (Fig. 4). No significant change in the abundance of nannoplankton cells after $24 \mathrm{~h}$ was detected in either ambient conditions or the two $\mathrm{pCO}_{2}$ treatments compared to the variance observed in the T0 samples. The presence or absence of copepods in the incubations did not make a significant impact in the majority of instances. However in the $1000 \mu$ atm treatment of E01 271, and at ambient conditions in E04 274, there was a significant enhancement in nannoplankton abundance when copepods were present.

Relationship between TEP and microbial abundance In the control incubations (ambient conditions without the presence of copepods), there was a general negative trend between relative changes in TEP concentration and bacterial cell abundance, although the relationship was not significant (ANOVA, $F=4.237, P=0.109,5 \mathrm{df}$, Fig. 5). This trend was mainly driven by the two Southern Ocean experiments (E03 274, E04 274), where there was a relatively large increase in TEP in E03 274 associated with a fall in bacterial abundance and a similarly large decrease in TEP in E04 274, where bacterial abundance increased. The relative changes in TEP were less marked in incubations that contained copepods. Overall, the relationship between TEP and bacteria was weak but potentially negative, with neither increases in $p \mathrm{CO}_{2}$ levels nor the presence of copepods having a strong impact on the relationship. 
400 A similar pattern was observed with regards the relationship between the relative change in TEP

401 concentration and nannoplankton abundance (Fig. 6). As with the bacteria, some of the highest rates

402 of change in nannoplankton were observed in the E04 274 experiment, where numbers increased 2

403 fold when incubated in the control incubations and 1.5 fold in all incubations containing copepods.

404 Correspondingly, there was a drop in TEP concentrations by almost $50 \%$ over $24 \mathrm{~h}$. By contrast, in

405 E03 274, nannoplankton abundance almost halved in the control incubations where there was a

406 concomitant doubling in TEP concentration. These two extremities were the main drivers of a

407 negative relationship between TEP concentration and nannoplankton abundance that was

408 particularly evident in the control incubations. Nevertheless, the trend did not prove to be significant

$409(F=6.346, P=0.065,5 d f)$. This trend was weaker in incubations containing copepods either in

410 ambient conditions or at raised $p \mathrm{CO}_{2}$ levels.

411 Phytoplankton community response In the majority of control incubations (i.e. ambient conditions,

412 no copepods), the abundance of phytoplankton cells increased over $24 \mathrm{~h}$, many by between 1 and 5

413 fold (Bottle effects, Table 5). These increases were observed across all four of the major

414 phytoplankton taxa counted (diatoms, dinoflagellates, ciliates and flagellates). The exception was

415 experiment E04 274, where cell abundance of diatoms, dinoflagellates and ciliates in control

416 incubations decreased.

417 The impact of copepods on phytoplankton cell abundance was mixed, with cell numbers increasing

418 in some instances and decreasing in others (Copepod effects, Table 5). No major phytoplankton

419 taxon either universally increased or decreased across all experiments when incubated in ambient

420 conditions with copepods, rather, responses varied according to taxon in each incubation. For

421 example, in experiment E01 271, all taxa continued to increase in cell numbers when copepods were

422 present while, in E05 271, all but the flagellates decreased.

423 Similarly mixed responses in phytoplankton cell abundance were observed in the $p \mathrm{CO}_{2}$ treatments

424 (Treatment effects, Table 5, Fig. 7). Compared to the responses observed in ambient conditions, 
some taxa responded negatively and other positively to increased $p \mathrm{CO}_{2}$ within the same experiment

426 (e.g. E03 271, E03 274). However, in two experiments (E01 271 and E04 274), all 4 major

427 phytoplankton taxa responded negatively to both the $750 \mu$ atm and $1000 \mu$ atm treatments when copepods were present. Of particular interest however was the response of dinoflagellates, in which there was a negative response within the incubations containing copepods at both $750 \mu$ atm and $1000 \mu$ atm $p \mathrm{CO}_{2}$ across all experiments while, in the corresponding incubations without copepods, the response was almost wholly positive. The difference in the dinoflagellate response between incubations containing copepods to those without copepods was significant in both the $750 \mu$ atm and $1000 \mu$ atm treatments (paired t-test: $750 \mu$ atm $\mathrm{t}=-3.38, \mathrm{P}=0.02,5 \mathrm{df} ; 1000 \mu$ atm $\mathrm{t}=-3.38, \mathrm{P}=$ 0.02). Such a consistent response to the presence or absence of copepods at raised $p \mathrm{CO}_{2}$ levels was not observed in the other major phytoplankton taxa.

Copepod response Compared to the variability observed in animals that were frozen immediately after capture (T0 population), there was no significant increase in the carbon content of copepods incubated for $24 \mathrm{~h}$ or $96 \mathrm{~h}$ in any of the treatments (Table 4). Over the course of the experiments therefore, the incubated copepods did not appear to increase or decrease in body mass to a detectable level.

$\mathrm{C}: \mathrm{N}$ mass ratios of incubated copepods also did not appear to differ significantly from the T0 populations in the majority of instances (Fig. 8), indicating that copepods neither added to nor used for $96 \mathrm{~h}$ in ambient conditions (Kruskall-Wallis 1-way ANOVA, $\mathrm{H}=18.07, \mathrm{P}=0.006,6 \mathrm{df}$ ). Nevertheless, on the whole, neither the length of the incubation nor the addition of $p \mathrm{CO}_{2}$ had an acute influence on copepod body mass or body condition. 


\section{Discussion}

451 The present study carried out short-term (up to $4 \mathrm{~d}$ ) incubation experiments of natural open-ocean

452 communities with and without the presence of grazing copepods in microcosms in which $p \mathrm{CO}_{2}$ levels

453 had been manipulated. The major advantage of the approach was in the repetition of the same

454 experimental technique on a diverse range of polar and sub-polar natural communities. The addition

455 of a mesozooplankton grazer to these microcosms added to the complexity of the experimental

456 system and made the interpretation of results more challenging. Nevertheless, we found that this

457 approach revealed responses to acute $\mathrm{OA}$ change. In particular, the impact of $p \mathrm{CO}_{2}$ treatments on

458 dinoflagellate cell numbers was consistently and significantly affected by the presence or absence of

459 copepods in the microcosms across each of the six diverse environments in which the experiments

460 were performed. By comparison, the other phytoplankton taxa did not show any consistent

461 response between treatments or experiments.

462 This study also set out to determine whether the widely reported observation of increased TEP as a

463 result of $\mathrm{CO}_{2}$ perturbation was prominent within a multi-trophic level experimental setup, and

464 whether this had any impact on the microbial community. We found that TEP increased naturally at

465 varying rates within control microcosms (i.e. ambient conditions without copepods). However,

466 elevated $p \mathrm{CO}_{2}$ treatments resulted in significant increases in TEP concentrations in some instances,

467 but no change or significant decreases in others. Furthermore, there was no significant relationship

468 between any observed change in TEP concentrations and the abundance of either bacteria or

469 nannoplankton. Indeed, although weak, the general trend was that both sets of microorganisms

470 were less abundant in those experiments where TEP was increasing most rapidly, which is contrary

471 to the expectation that these organisms thrive on increased TEP production (Bellerby et al. 2008).

\section{$472 \quad 4.1$ Sources of error}


473 One of the main methodological errors was in the under achievement of $p \mathrm{CO}_{2}$ targets in certain

474 experiments. Although the manipulations were successful in elevating DIC levels while maintaining a

475 constant TA, the measured $\mathrm{pCO}_{2}$ were sometimes several hundred $\mu$ atm below their target levels.

476 Discrepancies between measured $p \mathrm{CO}_{2}$ values and those calculated from DIC and TA have been

477 previously identified, particularly at high $p \mathrm{CO}_{2}$ levels (Hoppe et al. 2010, Hoppe et al. 2012). Amongst

478 the sources of error are uncertainties in calculation of the carbonate system, miscalculations of the

479 perturbation amounts, and handling errors when adding the chemicals to the incubation bottles.

480 There is also the potential for measurement error, which we estimated to be up to $60 \mu$ atm $p \mathrm{CO}_{2}$

481 when also including errors propagated in the calculation of the carbonate system. $p \mathrm{CO}_{2}$ levels within

482 the bottles were also subject to drift during the period of incubation, by an average of $36 \mu$ atm after

$48324 \mathrm{~h}$ and $60 \mu \mathrm{atm}$ after $96 \mathrm{~h}$. For this reason, the following discussion does not emphasise the

484 precise differences in the response to the two different $p \mathrm{CO}_{2}$ treatments but focuses more on the

485 consistency of responses between all incubations where $p \mathrm{CO}_{2}$ was manipulated.

\subsection{Dinoflagellate response to acute $p \mathrm{CO}_{2}$ elevation}

Our study found a significant difference in the response of dinoflagellates to acute $p \mathrm{CO}_{2}$ elevation, depending on the presence or absence of grazing copepods. Across all six experiments, there was a decline in dinoflagellate cell numbers in raised $\mathrm{pCO}_{2}$ levels when copepods were present, whereas dinoflagellate numbers increased when copepods were absent. No significant change was observed in any of the other major phytoplankton taxa. One explanation for this pattern is the direct impact of copepods on dinoflagellates in that the feeding behaviour and preferences of the copepods alter under enhanced $p \mathrm{CO}_{2}$ conditions, resulting in them selecting dinoflagellates to a greater extent than under ambient conditions. Alternatively, the presence of copepods may have had an indirect negative effect on dinoflagellate abundance when $p \mathrm{CO}_{2}$ levels were raised.

Support for the direct impact of copepods on dinoflagellates assumes that dinoflagellates become an increasingly suitable food item under elevated $p \mathrm{CO}_{2}$. Kleppel et al. (1991) was one of the first to 
argue that dinoflagellates are more nutritious than diatoms to zooplankton grazers. Dinoflagellates

contain 1.1-3.5 times more carbohydrate and 1.8-6 times more lipid than diatoms of equivalent

volume (Hitchcock 1982). Laboratory experiments have also shown that diets containing certain dinoflagellates enhance copepod egg production rates (Stoecker and Egloff 1987) whereas diatoms could suppress these rates (Miralto et al. 1999, lanora et al. 2004, although see Irigoien et al. 2002).

Nevertheless, to explain the pattern in the present study, dinoflagellates must not only be the prey

item of choice, but become increasingly preferred when $p \mathrm{CO}_{2}$ is raised. Under high $p \mathrm{CO}_{2} \mathrm{conditions}_{\text {, }}$ increasing carbon availability has the potential to change the stoichiometry of nutrients to primary producers. Carbon to nutrient ratios, which are already comparatively high in diatoms, will increase under such scenarios, making them of inferior quality to herbivorous consumers (Sterner and Elser 2002, Boersma et al. 2008, Malzahn et al. 2007, Schoo et al. 2013, Nobili et al 2013). The lower enzymatic specificity for $\mathrm{CO}_{2}$ in dinoflagellates makes them less responsive to $\mathrm{CO}_{2}$ enrichment and their carbon to nutrient ratios are less affected than diatoms (Tortell 2000), and they retain their quality as food items. Consumers, such as calanoid copepods, are more constrained with respect to their body nutrient composition than primary producers and thus have to cope with excess amounts of carbon relative to essential nutrients since they aim to maintain homeostasis (Sterner and Elser 2002). Selection of the most stoichiometrically suitable food items is likely to play a major role in maintaining this homeostasis. Nevertheless, this selectively may alter during different life-stages, and carbon-rich foods may be preferable during phases when the copepods are actively storing reserves as fatty acids, particularly long chain polyunsaturated fatty acids. Such fatty acids may also be altered to varying extents in different phytoplankton taxa under enhanced $p \mathrm{CO}_{2}($ Wynn-Edwards et al. 2014).

Furthermore, a direct impact of copepods on dinoflagellates means that these grazers must have the capacity to select between different prey items (Kleppel 1993). There has been a long history of study and debate on the capacity of copepods to feed selectively, dating back to Esterly (1916). 
523 Copepods are generally thought of as filtration feeders, meaning that they principally capture

524 particles no smaller than the inter-setal distance on their feeding appendages. However, Koehl and

525 Strickler (1981) and Paffenhöfer et al. (1982) demonstrated that, in the low Reynolds number

526 environments in which they exist, copepods are suspension feeders where the second maxillae push

527 parcels of water containing particles towards the mouth rather than filtering particles from the

528 water. There is also abundant evidence that copepods can select based on food quality. For instance,

529 Mullin (1963) demonstrated that Calanus helgolandicus ingests more exponentially growing than

530 senescent diatoms per unit time. Cowles et al. (1988) showed that Acartia tonsa distinguishes

531 nutritional quality in mixtures of nutritionally rich and poor phytoplankton species. The same finding

532 was made by Kiørboe (1989) who further found a relationship between the quality of ingested food

533 and egg production rates. In summary, direct impacts of copepods on dinoflagellates at acutely

534 enhanced $p \mathrm{CO}_{2}$ levels is supported by other findings that enhanced $p \mathrm{CO}_{2}$ is likely to decrease the

535 nutritional value of dinoflagellates less than diatoms, and that copepods are capable of selecting

536 phytoplankton cells based on their quality as food items.

537 It is more difficult to find supporting evidence for the possibility that copepods have an indirect

538 negative impact on dinoflagellate abundance under enhanced $p \mathrm{CO}_{2}$ conditions. One means in which

539 this could occur is that the copepods may alter the chemical environment, through respiration and

540 excretion, making it less suited to dinoflagellate growth when $p \mathrm{CO}_{2}$ is raised. Flynn et al. (2015)

541 found that altering nutrient conditions changes the competitive balance between different

542 phytoplankton species exposed to OA. However, there was little evidence that nutrient levels were

543 significantly altered after $24 \mathrm{~h}$ and $\mathrm{CO}_{2}$ becomes more, rather than less, available as a result of the

544 experimental treatments and should be non-limiting to cell division. Another possibility is that the

545 copepods grazing on other prey items may cause a trophic cascade, releasing predatory pressure on

546 other dinoflagellates grazers. However, dinoflagellates are relatively large cells and are unlikely to be

547 major prey items of any other heterotrophic organisms within the incubations other than copepods. 
548 Therefore, the direct impact of copepods on dinoflagellates through selective grazing is the most

549 likely explanation for the observed pattern.

\section{$550 \quad 4.3$ Copepod body condition}

551 We found there to be no detectable change in copepod body condition in CV and females stages of 552 Calanus finmarchicus/glacialis, C. hyperboreus, and Calanoides acutus, assessed in terms of the C:N 553 mass ratio, as a result of raised $p \mathrm{CO}_{2}$ treatments either after $24 \mathrm{~h}$ or $96 \mathrm{~h}$ of incubation. Neither was 554 there a concomitant rise or fall in the mass of carbon and nitrogen, which would indicate a change in 555 body mass over the incubation period. The exception was experiment E05 271, where the C:N mass 556 ratio significantly increased. However, the same level of increase was observed in both ambient and 557 raised $p \mathrm{CO}_{2}$ conditions, indicating that this pattern was more likely to be a bottle effect than a 558 treatment effect.

The fact that there was little response to $p \mathrm{CO}_{2}$ treatments in any of the copepod species is consistent with the majority of other studies on the sensitivity of copepods to raised $\mathrm{CO}_{2}$. In terms of direct physiological responses, most studies have found no direct effects on copepods at $\mathrm{CO}_{2}$ levels within the range expected by the end of this century (Kurihara et al. 2004; Watanabe et al. 2006, Kurihara and Ishimatsu 2008, Zhang et al. 2011, Vehmaa et al. 2012, Weydmann et al., 2012, McConville et al. 2013, Niehoff et al. 2013). It is to be noted that the majority of these studies focussed on adult females whereas only a few have concentrated on other life-history stages which are likely to show greater sensitivity to elevated $p \mathrm{CO}_{2}$ (Kurihara et al. 2004, Fitzer et al. 2012, Lewis et al. 2013, Cripps et al. 2014).

There has been less attention on how copepod body condition responds to changes in the quality of their food as a result of increased levels of $p \mathrm{CO}_{2}$. For instance, Urabe et al. (2003) found lower growth rates of the freshwater species Daphnia pulicaria at high $p \mathrm{CO}_{2}$ due to altered algal C:P ratios. Schoo et al. (2013) found that the copepod Acartia tonsa showed decreased development rate when 
572 fed the algae Rhodomonas salina grown under increased $p \mathrm{CO}_{2}$ levels. In a culture containing the

573 diatom Thalassiosira pseudonana and the copepod Acartia tonsa, Rossoll et al. (2012) found that

574 exposure to $\mathrm{pCO}_{2}$ levels of $750 \mu$ atm led to a decrease in polyunsaturated fatty acids in the diatoms

575 and a corresponding decrease in copepod egg production (Rossoll et al. 2012). Therefore, even

576 though it is likely that copepods have the ability to select food items based on their quality, their

577 stoichiometric homeostasis and growth potential will be affected when there is a lack of good

578 quality food items available. The diversity of food items in the incubation chambers in the present

579 study may have allowed the copepods in the present study to prevent decreases in body condition,

580 at least for the short term duration of the incubations.

\section{$581 \quad 4.4$ Net change in TEP}

582 TEP increased in all of the control incubations (i.e. ambient conditions, without copepods) to varying

583 degrees, with some of the highest rates of increase occurring in the most nutrient stressed sites

584 (North Sea, Barents Sea). These increases took some days to be detectable, with no significant

585 increases being found after $24 \mathrm{~h}$. When compared to the changes documented in the control

586 incubation, 4 out of the 6 experiments showed significant increases in the $1000 \mu$ atm $p \mathrm{CO}_{2}$

587 treatment, with the remaining 2 experiments either showing a neutral or negative change. Only 2 of

588 the experiments showed a significant increase in the $750 \mu \mathrm{atm} p \mathrm{CO}_{2}$ treatment, the remaining 4 not

589 showing any significant change. The impact of copepods on TEP concentrations was mixed, leading

590 to increased concentrations in some experiments but neutral or negative changes in others.

591 Initial studies on the influence of raised $p \mathrm{CO}_{2}$ on TEP formation found a relatively consistent pattern

592 of greater TEP formation when $p \mathrm{CO}_{2}$ levels were raised acutely (Bellerby et al. 2008, Weinbauer et

593 al. 2011). The prevailing hypothesis is that, under high $p \mathrm{CO}_{2}$ conditions, more of the organic carbon

594 fixed by photosynthesis is channelled into the dissolved fraction and released from the cells. This

595 leads to a greater standing stock of TEPs as the released matter coagulates into particulates. Higher 
concentration of TEP in surface waters is therefore believed to be one of the most predictable consequences of OA (Weinbauer et al. 2011).

Nevertheless, there has recently been some doubt regarding the universality of the response of TEP to increased $p \mathrm{CO}_{2}$ levels. In rolling tank experiments, where TEP was either in equilibrium or nonequilibrium with its precurors, Passow (2012) found that OA as expected in the future oceans had no impact on the process of TEP formation from its precursors. In field observations, MacGilchrist et al.

602 (2014) found a significant but highly variable effect of acute $p \mathrm{CO}_{2}$ increase on TEP production, with increased TEP production being closely linked to phytoplankton growth in some instances and as a result of greater amounts of TEP being produced per cell in others. The MacGilchrist et al. (2014) study used similar incubation techniques to the present study but was carried out in a variety of environmental settings in European shelf seas. Their findings match those of the present study in

607 that the TEP response to raised $p \mathrm{CO}_{2}$ levels is more likely to be dependent on the specific environmental setting and cannot be assumed to be universal.

As well as being conducted in high latitude environments, the present study differed from that of MacGilchrist et al. (2014) in introducing a further trophic level through the addition of grazing copepods. Zooplankton have been found to feed effectively on clusters of TEP (Passow and

612 Alldredge 1999, Ling and Alldredge 2003). Nevertheless, there was no consistent impact of copepods on TEP in the present study, suggesting that it is unlikely to be a preferred food item. This may be particularly the case given that TEP is carbon rich (Passow 2012) and of low quality relative to nutrient rich phytoplankton taxa such as dinoflagellates (Kleppel 1993).

\subsection{Response of bacteria and nannoplankton}

617 We found that there was no significant change in the abundance of either bacteria or nannoplankton in response to raised $p \mathrm{CO}_{2}$ levels. This is consistent with the results of mesocosm 
620 (Rochelle-Newall et al. 2004, Allgaier et al. 2008, Paulino et al 2008). Nevertheless, according to

621 Weinbauer et al. (2011), no study has shown a clear negative effect of elevated $p \mathrm{CO}_{2}$ on prokaryotic

622 production at $\mathrm{pH}$ levels relevant in the context of OA. Thus, our study supports the wider body of

623 data so far collected that suggests a neutral or positive effect of OA on the growth rate of

624 microorganism populations.

625 The relationship between the relative change in TEP concentrations and bacterial abundance in the

626 present study was not significant, although there was a trend of bacterial numbers decreasing as TEP

627 increased. The relationship between TEP concentration and nannoplankton abundance showed a

628 similar trend. Corzo et al. (2005), Passow et al. (2001), Hung et al. (2003) and Santschi et al. (2003)

629 have reported positive relationships between TEP and bacteria, whereas Passow and Alldredge

630 (1994) and Bhaskar and Bhosle (2006) found negative or no correlation at all. In the Southern Ocean,

631 Ortega-Retuerta et al. (2009) found a positive relationship between TEP and bacterial abundance

632 within the upper mixed layer, although the slope was relatively shallow. There was a much stronger

633 relationship below the mixed layer. It was proposed that the relationship was mediated by

634 phytoplankton and may not be a direct relationship between the two components. The present

635 study only considered the upper mixed layer community which may have constrained our ability to

636 identify any such relationship between TEP and microorganisms. Alternatively, it is possible that the

637 increase in TEP we consistently observed over the course of the incubation experiments was the

638 result of bottle effects to which the bacterial- and nannoplankton communities could not respond. In

639 summary, we found no evidence to support the view that the microbial community is stimulated by

640 the greater levels of TEP production that may result from acute increases in $p \mathrm{CO}_{2}$. 
642 This study completed six controlled microcosm experiments on natural communities extracted from

643 a diverse set of high latitude open-ocean sites and exposed to acute increases in $p \mathrm{CO}_{2}$. The spatial

644 diversity of the experiments allowed the determination of whether different communities showed

645 similar or differing responses to a common acute perturbation in $\mathrm{pCO}_{2}$. Although the short-term and

646 acute nature of the perturbation was not a true simulation of the changes likely to take place over

647 the coming decades in the natural environment, it did provide an insight into whether these differing

648 communities are equally placed in adapting to the predicted environmental changes. Across a range

649 of high latitude environments, we identified a similar trophic response in copepods to their

650 phytoplankton prey, which was induced by elevated $p \mathrm{CO}_{2}$. We also demonstrated that the response

651 of TEP to acute $p \mathrm{CO}_{2}$ perturbation depends on the precise set of environmental conditions and

652 cannot be assumed to be highly predictable. Trophic impacts on the body condition of the grazing

653 copepod community were not resolved and are better suited to longer-term experimental

654 approaches. 


\section{Acknowledgements}

656 This work was funded under the UK Ocean Acidification thematic programme (UKOA) via the UK

657 Natural Environment Research Council (NERC) grants NE/H017267/1 to GA Tarling, NE/H017348/1 to

658 T Tyrrell, EP Achterberg and CM Moore, NE/H017097/1 to AJ Poulton and MV Zubkov and

659 NE/H016988/1 to RJG Leakey. The UK Department of Environment, Food and Rural Affairs (Defra)

660 and the UK Department of Energy and Climate Change (DECC) also contributed to funding UKOA.

661 Our travel and work in Greenland, Iceland and Svalbard coastal and offshore waters was granted

662 thanks to permissions provided by the Danish, Icelandic and Norwegian diplomatic authorities. We

663 also thank the captains and crew of the RRS James Clark Ross during cruises JR271 and JR274, the

664 technical staff from the British Antarctic Survey, National Marine Facilities, and the Scottish

665 Association for Marine Science, Oban. Further thanks to P Enderlein for Bongo net maintenance, CM

666 Moore for assistance with acid-base manipulations, M Esposito and R Sanders for macronutrient

667 data, H Lawson for Lugols count data, C Georges for JR274 flow cytometry data, P Geissler for

668 elemental analyses and M Ribas-Ribas (NOC) and R Thomas (BODC) for data management. We are

669 grateful to R Leakey for leading cruise JR271 and for critical comments on this work. 


\section{References}

671 Allgaier, M., Riebesell, U., Vogt, M., Thyrhaug, R., Grossart, H.-P., 2008. Coupling of heterotrophic

672 bacteria to phytoplankton bloom development at different $\mathrm{pCO}_{2}$ levels: a mesocosm study.

673 Biogeosciences Discuss. 5, 317-359.

674 Beaufort, L., Probert, I., de Garidel-Thoron, T., Bendif, E., Ruiz-Pino, D., Metzl, N., Goyet, C., Buchet,

675 N., Coupel, P., Grelaud, M., 2011. Sensitivity of coccolithophores to carbonate chemistry and 676 ocean acidification. Nature 476, 80-83.

677 Bellerby, R.G.J., Schulz, K.G., Riebesell, U., Neill, C., Nondal, G., Heegaard, E., Johannessen, T., Brown, 678 K.R., 2008. Marine ecosystem community carbon and nutrient uptake stoichiometry under 679 varying ocean acidification during the PeECE III experiment. Biogeosciences 5, 1517-1527.

Bhaskar, P., Bhosle, N.B., 2006. Dynamics of transparent exopolymeric particles (TEP) and particleassociated carbohydrates in the Dona Paula bay, west coast of India. J. Earth Syst. Sci. 115, 403413.

Boersma, M., Aberle, N., Hantzsche, F.M., Schoo, K.L., Wiltshire, K.H., Malzahn, A.M., 2008. Nutritional limitation travels up the food chain. Int. Rev. Hydrobiol. 93, 479-488.

Bradshaw, A.L., Brewer, P.G., Shafer, D.K., Williams, R.T., 1981. Measurements of total carbon dioxide and alkalinity by potentiometric titration in the GEOSECS program. Earth Planet. Sci. Lett. 55, 99115, doi:99110.91016/90012-99821X(99181)90090-X.

Cooley, S.R., Kite-Powell, H.L., Doney, S.C., 2009. Ocean Acidification's potential to alter global marine ecosystem services. Oceanography 22, 172-181.

Corzo, A., Rodríguez-Gálvez, S., Lubian, L., Sobrino, C., Sangrá, P., Martínez, A., 2005. Antarctic marine bacterioplankton subpopulations discriminated by their apparent content of nucleic acids differ in their response to ecological factors. Polar Biol. 29, 27-39.

Cowles, T., Olson, R., Chisholm, S., 1988. Food selection by copepods: discrimination on the basis of food quality. Mar. Biol. 100, 41-49.

Cripps, G., Lindeque, P., Flynn, K.J., 2014. Have we been underestimating the effects of ocean 
acidification in zooplankton? Global Change Biol. 20, 3377-3385.

de Nooijer, L.J., Toyofuku, T., Kitazato, H., 2009. Foraminifera promote calcification by elevating their intracellular pH. P. Natl. Acad. Sci. USA 106, 15374-15378.

Dickson, A.G., 1990. Standard potential of the reaction: $\mathrm{AgCl}(\mathrm{s})+12 \mathrm{H} 2(\mathrm{~g})=\mathrm{Ag}(\mathrm{s})+\mathrm{HCl}(\mathrm{aq})$, and and the standard acidity constant of the ion HSO4- in synthetic sea water from 273.15 to $318.15 \mathrm{~K}$, J. Chem. Thermodyn. 22, 13127, doi:13110.11016/10021-19614(13190)90074-Z.

Dickson, A.G., Millero, F.J., 1987. A comparison of the equilibrium constants for the dissociation of carbonic acid in seawater media. Deep-Sea Res. 34, 1733-1743.

Dickson, A.G., Sabine, C.L., Christian, J.R., 2007. Guide to best practices for ocean $\mathrm{CO}_{2}$

Doney, S.C., Ruckelshaus, M., Emmett Duffy, J., Barry, J.P., Chan, F., English, C.A., Galindo, H.M., Grebmeier, J.M., Hollowed, A.B., Knowlton, N., 2012. Climate change impacts on marine ecosystems. Ann. Rev. Mar. Sci. 4, 11-37.

Engel, A., 2002. Direct relationship between $\mathrm{CO}_{2}$ uptake and transparent exopolymer particles production in natural phytoplankton. J. Plankt. Res. 24, 49-53.

Engel, A., Schulz, K., Riebesell, U., Bellerby, R., Delille, B., Schartau, M., 2008. Effects of $\mathrm{CO}_{2}$ on particle size distribution and phytoplankton abundance during a mesocosm bloom experiment (PeECE II). Biogeosciences Discuss. 5, 509-521.

Engel, A., Thoms, S., Riebesell, U., Rochelle-Newall, E., Zondervan, I., 2004. Polysaccharide aggregation as a potential sink of marine dissolved organic carbon. Nature 428, 929-932.

Esterly, C.O., 1916. The feeding habits and food of pelagic copepods and the question of nutrition by organic substances in solution in the water. Unlv. Calif. Publ. Zool. 16, 171-184.

Fabry, V.J., McClintock, J.B., Mathis, J.T., Grebmeier, J.M., 2009. Ocean Acidification at high latitudes: the bellwether. Oceanography 22, 160-171.

Fitzer, S.C., Caldwell, G.S., Close, A.J., Clare, A.S., Upstill-Goddard, R.C., Bentley, M.G., 2012. Ocean 
acidification induces multi-generational decline in copepod naupliar production with possible conflict for reproductive resource allocation. J. Exp. Mar. Biol. Ecol. 418, 30-36.

Flynn KJ, Clark DR, Mitra A, Fabian H, Hansen PJ, Glibert PM, Wheeler GL, Stoecker DK, Blackford JC, Brownlee C (2015) Ocean acidification with (de) eutrophication will alter future phytoplankton growth and succession. Proc. R. Soc. London B 282, 20142604.

Gattuso, J.-P., Gao, K., Lee, K., Rost, B., Schulz, K.G., 2010. Approaches and tools to manipulate the carbonate chemistry, in: Riebesell, U., Fabry, V.J., Hansson, L., Gattuso, J.P. (Eds.), Guide to Best Practices for Ocean Acidification Research and Data Reporting. Publications Office of the European Union, Luxembourg, p. 263 pp.

Hitchcock, G.L., 1982. A comparative study of the size-dependent organic composition of marine diatoms and dinoflagellates. J. Plankt. Res. 4, 363-377.

Hoppe, C., Langer, G., Rokitta, S., Wolf-Gladrow, D., Rost, B., 2010. On $\mathrm{CO}_{2}$ pertubation experiments: over-determination of carbonate chemistry reveals inconsistencies. Biogeosciences Discuss. 7, $1707-1726$

Hoppe, C.J.M., Langer, G., Rokitta, S.D., Wolf-Gladrow, D.A., Rost, B., 2012. Implications of observed inconsistencies in carbonate chemistry measurements for ocean acidification studies. Biogeosciences 9, 2401-2405.

Hung, C.C., Guo, L., Schultz, G.E., Pinckney, J.L., Santschi, P.H., 2003. Production and flux of carbohydrate species in the Gulf of Mexico. Global Biogeochem. Cy. 17, 1055, doi:1010.1029/2002GB001988.

Hutchins, D., Fu, F.-X., Zhang, Y., Warner, M., Feng, Y., Portune, K., Bernhardt, P., Mulholland, M., 2007. $\mathrm{CO}_{2}$ control of Trichodesmium $\mathrm{N}_{2}$ fixation, photosynthesis, growth rates, and elemental ratios: implications for past, present, and future ocean biogeochemistry. Limnol. Oceanogr. 52, 1293-1304.

Ianora, A., Miralto, A., Poulet, S.A., Carotenuto, Y., Buttino, I., Romano, G., Casotti, R., Pohnert, G., Wichard, T., Colucci-D'Amato, L., 2004. Aldehyde suppression of copepod recruitment in blooms 
of a ubiquitous planktonic diatom. Nature 429, 403-407.

Irigoien, X., Harris, R.P., Verheye, H.M., Joly, P., Runge, J., Starr, M., Pond, D., Campbell, R., Shreeve, R., Ward, P., 2002. Copepod hatching success in marine ecosystems with high diatom concentrations. Nature 419, 387-389.

Kérouel, R., Aminot, A., 1997. Fluorometric determination of ammonia in sea and estuarine waters by direct segmented flow analysis. Mar. Chem. 57, 265-275.

Kiørboe, T., 1989. Phytoplankton growth rate and nitrogen content: implications for feeding and fecundity in a herbivorous copepod. Mar. Ecol. Prog. Ser 55, 229-234.

Kirkwood, D.S., 1996. Nutrients: a practical note on their determination in seawater. ICES, Copenhagen, Denmark.

Kleppel, G., 1993. On the diets of calanoid copepods. Mar. Ecol. Prog. Ser 99, 183-183.

Kleppel, G.S., Holliday, D., Pieper, R., 1991. Trophic interactions between copepods and microplankton: a question about the role of diatoms. Limnol. Oceanogr. 36, 172-178.

Koehl, M., Strickler, J.R., 1981. Copepod feeding currents: Food capture at low Reynolds numbers. Limnol. Oceanogr. 26, 1062-1073.

Kurihara, $\mathrm{H}$., Ishimatsu, A., 2008. Effects of high $\mathrm{CO}_{2}$ seawater on the copepod (Acartia tsuensis) through all life stages and subsequent generations. Mar. Pollut. Bull. 56, 1086-1090.

Kurihara, H., Shimode, S., Shirayama, Y., 2004. Effects of raised $\mathrm{CO}_{2}$ concentration on the egg production rate and early development of two marine copepods (Acartia steueri and Acartia erythraea). Mar. Pollut. Bull. 49, 721-727.

Lee, K., Kim, T.-W., Byrne, R.H., Millero, F.J., Feely, R.A., Liu, Y.-M., 2010. The universal ratio of boron to chlorinity for the North Pacific and North Atlantic oceans. Geochim. Cosmochim. Ac. 74, 18011811.

Lewis, C.N., Brown, K.A., Edwards, L.A., Cooper, G., Findlay, H.S., 2013. Sensitivity to ocean acidification parallels natural $\mathrm{pCO}_{2}$ gradients experienced by Arctic copepods under winter sea ice. Proc. Natl. Acad. Sci. USA 110, E4960-E4967. 
Lewis, E., Wallace, D.W.R., 1998. Program Developed for $\mathrm{CO}_{2}$ System Calculations. ORNL/CDIAC-105. Carbon Dioxide Information Analysis Center, Oak Ridge National Laboratory, U.S. Department of Energy, Oak Ridge, Tennessee.

Ling, S.C., Alldredge, A.L., 2003. Does the marine copepod Calanus pacificus consume transparent exopolymer particles (TEP)? J. Plankt. Res. 25, 507-515.

MacGilchrist, G., Shi, T., Tyrrell, T., Richier, S., Moore, C., Dumousseaud, C., Achterberg, E.P., 2014. Effect of enhanced $\mathrm{pCO}_{2}$ levels on the production of dissolved organic carbon and transparent exopolymer particles in short-term bioassay experiments. Biogeosciences 11, 3695-3706.

Malzahn, A.M., Aberle, N., Clemmesen, C., Boersma, M., 2007. Nutrient limitation of primary producers affects planktivorous fish condition. Limnol. Oceanogr. 52, 2062-2071.

Marie, D., Partensky, F., Jacquet, S., Vaulot, D., 1997. Enumeration and cell cycle analysis of natural populations of marine picoplankton by flow cytometry using the nucleic acid stain SYBR Green I. Appl. Environ. Microbiol. 63, 186-193.

McConville, K., Halsband, C., Fileman, E.S., Somerfield, P.J., Findlay, H.S., Spicer, J.I., 2013. Effects of elevated $\mathrm{CO}_{2}$ on the reproduction of two calanoid copepods. Mar. Pollut. Bull. 73, 428-434.

McNeil, B.I., Matear, R.J., 2008. Southern Ocean acidification: A tipping point at 450-ppm atmospheric CO2. Proc. Natl. Acad. Sci. U.S.A. 105, 18860-18864.

Mehrbach, C., Culberson, C.H., Hawley, J.E., Pytkowicx, R.M., 1973. Measurement of the apparent dissociation constants of carbonic acid in seawater at atmospheric pressure. Limnol. Oceanogr. 18, 897-907.

Miralto, A., Barone, G., Romano, G., Poulet, S., lanora, A., Russo, G., Buttino, I., Mazzarella, G., Laabir, M., Cabrini, M., 1999. The insidious effect of diatoms on copepod reproduction. Nature $402,173-176$.

Mullin, M.M., 1963. Some factors affecting the feeding of marine copepods in the genus Calanus. Limnol. Oceanogr. 8, 239-250.

Niehoff, B., Knüppel, N., Daase, M., Czerny, J., Boxhammer, T., 2013. Mesozooplankton community 
development at elevated $\mathrm{CO}_{2}$ concentrations: results from a mesocosm experiment in an Arctic fjord. Biogeosciences 10, 1391-1406.

Nobili, R., Robinson, C., Buitenhuis, E., Castellani, C., 2013. Food quality regulates the metabolism and reproduction of Temora longicornis. Biogeosciences Discuss. 10, 3203-3239.

Ortega-Retuerta, E., Frazer, T.K., Duarte, C.M., Ruiz-Halpern, S., Tovar-Sánchez, A., Arrieta, J.M., Rechea, I., 2009. Biogeneration of chromophoric dissolved organic matter by bacteria and krill in the Southern Ocean. Limnol. Oceanogr. 54, 1941-1950.

Paffenhöfer, G.-A., Strickler, J., Alcaraz, M., 1982. Suspension-feeding by herbivorous calanoid copepods: a cinematographic study. Mar. Biol. 67, 193-199.

Passow, U., 2002. Transparent exopolymer particles (TEP) in aquatic environments. Prog. Oceanogr. $55,287-333$.

Passow, U., 2012. The abiotic formation of TEP under different ocean acidification scenarios. Mar. Chem. 128, 72-80.

Passow, U., Alldredge, A., 1995. A dye binding assay for the spectrophotometric measurement of transparent exopolymer particles (TEP). Limnol. Oceanogr. 40, 1326-1335.

Passow, U., Alldredge, A.L., 1994. Distribution, size and bacterial-colonization of transparent exopolymer particles (TEP) in the ocean. Mar. Ecol. Prog. Ser. 113, 185-198.

Passow, U., Alldredge, A.L., 1999. Do transparent exopolymer particles (TEP) inhibit grazing by the euphausiid Euphausia pacifica? J. Plankt. Res. 21, 2203-2217.

Passow, U., Shipe, R., Murray, A., Pak, D., Brzezinski, M., Alldredge, A., 2001. The origin of transparent exopolymer particles (TEP) and their role in the sedimentation of particulate matter. Cont. Shelf Res. 21, 327-346.

Paulino, A., Egge, J., Larsen, A., 2008. Effects of increased atmospheric $\mathrm{CO}_{2}$ on small and intermediate sized osmotrophs during a nutrient induced phytoplankton bloom. Biogeosciences 5, 739-748.

Poulton, A.J., Moore, C.M., Seeyave, S., Lucas, M.I., Fielding, S., Ward, P., 2007. Phytoplankton 
community composition around the Crozet Plateau, with emphasis on diatoms and Phaeocystis. Deep-Sea Res. II 54, 2085-2105.

Redfield, A., 1958. The biological control of chemical factors in the environment. Amer. Sci, 205-221.

Richier, S., Achterberg, E., Dumousseaud, C., Poulton, A., Suggett, D., Tyrrell, T., Zubkov, M., Moore, C., 2014. Carbon cycling and phytoplankton responses within highly-replicated shipboard carbonate chemistry manipulation experiments conducted around Northwest European Shelf Seas. Biogeosciences Discuss 11, 3489-3534.

Riebesell, U., Fabry, V.J., Hansson, L., Gattuso, J.-P., 2010. Guide to best practices for ocean acidification research and data reporting. Publications Office of the European Union Luxembourg.

Riebesell, U., Gattuso, J.-P., Thingstad, T., Middelburg, J., 2013. Preface" Arctic ocean acidification: pelagic ecosystem and biogeochemical responses during a mesocosm study". Biogeosciences 10, $5619-5626$.

Riebesell, U., Tortell, P., 2011. Effects of ocean acidification on pelagic organisms and ecosystems, in: Gattuso, J., Hanson, L. (Eds.), Ocean Acidification. Oxford University Press, Oxford, pp. 99-121.

Riebesell, U., Zondervan, I., Rost, B., Tortell, P.D., Zeebe, R.E., Morel, F.M., 2000. Reduced calcification of marine plankton in response to increased atmospheric $\mathrm{CO}_{2}$. Nature 407, 364-367.

Rochelle-Newall, E., Delille, B., Frankignoulle, M., Gattuso, J.-P., Jacquet, S., Riebesell, U., Terbrüggen, A., Zondervan, I., 2004. Chromophoric dissolved organic matter in experimental mesocosms maintained under different $\mathrm{pCO}_{2}$ levels. Mar. Ecol. Prog. Ser. 272, 25-31.

Rossoll, D., Bermúdez, R., Hauss, H., Schulz, K.G., Riebesell, U., Sommer, U., Winder, M., 2012. Ocean acidification-induced food quality deterioration constrains trophic transfer. Plos One 7, e34737.

Rossoll, D., Sommer, U., Winder, M., 2013. Community interactions dampen acidification effects in a coastal plankton system. Mar. Ecol. Prog. Ser 486, 37-46.

Sabine, C.L., Feely, R.A., Gruber, N., Key, R.M., Lee, K., Bullister, J.L., Wanninkhof, R., Wong, C.S., Wallace, D.W.R., Tilbrook, B., Millero, F.J., Peng, T.H., Kozyr, A., Ono, T., Rios, A.F., 2004. The oceanic sink for anthropogenic $\mathrm{CO}_{2}$. Science $305,367-371$. 
Santschi, P.H., Hung, C.C., Schultz, G., Alvarado-Quiroz, N., Guo, L., Pinckney, J., Walsh, I., 2003. Control of acid polysaccharide production and ${ }^{234} \mathrm{Th}$ and POC export fluxes by marine organisms. Geophys. Res. Lett. 30.

Schoo, K.L., Malzahn, A.M., Krause, E., Boersma, M., 2013. Increased carbon dioxide availability alters phytoplankton stoichiometry and affects carbon cycling and growth of a marine planktonic herbivore. Mar. Biol. 160, 2145-2155.

Simon, M., Grossart, H.-P., Schweitzer, B., Ploug, H., 2002. Microbial ecology of organic aggregates in aquatic ecosystems. Aquat. Microb. Ecol. 28, 175-211.

Steinacher, M., Joos, F., Frolicher, T., Plattner, G.-K., Doney, S.C., 2009. Imminent ocean acidification in the Arctic projected with the NCAR global coupled carbon cycle-climate model. Biogeosciences 6, 515-533.

Sterner, R.W., Elser, J.J., 2002. Ecological stoichiometry: the biology of elements from molecules to the biosphere. Princeton University Press.

Stoecker, D.K., Egloff, D.A., 1987. Predation by Acartia tonsa Dana on planktonic ciliates and rotifers. J. Exp. Mar. Biol. Ecol. 110, 53-68.

Tortell, P.D., 2000. Evolutionary and ecological perspectives on carbon acquisition in phytoplankton. Limnol. Oceanogr. 45, 744-750.

Tortell, P.D., DiTullio, G.R., Sigman, D.M., Morel, F., 2002. $\mathrm{CO}_{2}$ effects on taxonomic composition and nutrient utilization in an Equatorial Pacific phytoplankton assemblage. Mar. Ecol. Prog. Ser 236, $37-43$.

Urabe, J., Togari, J., Elser, J.J., 2003. Stoichiometric impacts of increased carbon dioxide on a planktonic herbivore. Global Change Biol. 9, 818-825.

van Heuven, S., Pierrot, D., Rae, J.W.B., E., L., Wallace, D.W.R., 2011. MATLAB Program Developed for CO2 System Calculations. ORNL/CDIAC-105b. Carbon Dioxide Information Analysis Center, Oak Ridge National Laboratory, U.S. Department of Energy, Oak Ridge, Tennessee.

Vehmaa, A., Brutemark, A., Engström-Öst, J., 2012. Maternal effects may act as an adaptation 
mechanism for copepods facing pH and temperature changes. Plos One 7, e48538.

Watanabe, Y., Yamaguchi, A., Ishida, H., Harimoto, T., Suzuki, S., Sekido, Y., Ikeda, T., Shirayama, Y., Mac Takahashi, M., Ohsumi, T., 2006. Lethality of increasing $\mathrm{CO}_{2}$ levels on deep-sea copepods in the western North Pacific. J. Oceanogr. 62, 185-196.

Weinbauer, M.G., Mari, X., Gattuso, J.-P., 2011. Effect of ocean acidification on the diversity and activity of heterotrophic marine microorganisms, in: Gattuso, J.P., Hansson, L. (Eds.), Ocean acidification. Oxford University Press, Oxford, pp. 83-98.

Weydmann, A., Søreide, J.E., Kwasniewski, S., Widdicombe, S., 2012. Influence of $\mathrm{CO}_{2}$-induced acidification on the reproduction of a key Arctic copepod Calanus glacialis. J. Exp. Mar. Biol. Ecol. $428,39-42$.

Whiteley, N., 2011. Physiological and ecological responses of crustaceans to ocean acidification. Mar. Ecol. Prog. Ser. 430, 257-271.

Wynn-Edwards, C., King, R., Davidson, A., Wright, S., Nichols, P.D., Wotherspoon, S., Kawaguchi, S., Virtue, P., 2014. Species-specific variations in the nutritional quality of Southern Ocean phytoplankton in response to elevated $\mathrm{pCO}_{2}$. Water $6,1840-1859$.

Zar, J.H., 1996. Biostatistical analysis. Prentice Hall International, Englewood Cliffs, New Jersey.

Zhang, D., Li, S., Wang, G., Guo, D., 2011. Impacts of $\mathrm{CO}_{2}$-driven seawater acidification on survival, egg production rate and hatching success of four marine copepods. Acta Oceanol. Sin. 30, 86-94.

Zubkov, M.V., Burkill, P.H., 2006. Syringe pumped high speed flow cytometry of oceanic phytoplankton. Cytom. Part A 69A, 1010-1019.

Zubkov, M.V., Burkill, P.H., Topping, J.N., 2007. Flow cytometric enumeration of DNA-stained oceanic planktonic protists. J. Plankton Res. 29, 79-86. 
Tables

\begin{tabular}{|c|c|c|c|c|c|c|c|}
\hline Bioassay & Date & Location & Latitude $\left({ }^{\circ}\right)$ & $\begin{array}{l}\text { Longitude } \\
\left({ }^{\circ}\right)\end{array}$ & $\begin{array}{l}\text { Water } \\
\text { depth }(\mathrm{m})\end{array}$ & $\begin{array}{l}\text { Mixed-layer } \\
\text { depth }(\mathrm{m})\end{array}$ & Incubated taxa \\
\hline E01 271 & $3 / 6 / 12$ & North Sea & 56.26664 & 2.63319 & 74 & $\begin{array}{l}13.600 \\
(2.408)\end{array}$ & Calanus finmarchicus $\mathrm{CV}$ \\
\hline E03 271 & $13 / 6 / 12$ & Arctic & 76.17524 & 2.54953 & 3758 & $\begin{array}{l}29.667 \\
(7.506)\end{array}$ & Calanus hyperboreus CV \\
\hline E04 271 & $18 / 6 / 12$ & Arctic & 78.28063 & 4.28433 & 2257 & $\begin{array}{r}11.000 \\
(1.414)\end{array}$ & Calanus hyperboreus CV \\
\hline E05 271 & $24 / 6 / 12$ & Arctic & 72.89080 & 26.00273 & 362 & $\begin{array}{l}44.000 \\
(4.301)\end{array}$ & $\begin{array}{l}\text { Calanus } \\
\text { finmarchicus/glacialis } \mathrm{CV}\end{array}$ \\
\hline E03 274 & $25 / 1 / 13$ & $\begin{array}{l}\text { Southern } \\
\text { Ocean }\end{array}$ & -52.68930 & -36.62303 & 2445 & $\begin{array}{r}62.600 \\
(10.569) \\
\end{array}$ & Calanoides acutus $\mathrm{CV}$ \\
\hline E04 274 & $1 / 2 / 13$ & $\begin{array}{l}\text { Southern } \\
\text { Ocean }\end{array}$ & -58.08701 & -25.92901 & 2899 & $\begin{array}{r}35.828 \\
(5.824)\end{array}$ & $\begin{array}{l}\text { Calanoides acutus CV } \\
\text { and female }\end{array}$ \\
\hline
\end{tabular}

Table 1: Locations and attributes of the six experimental stations, including the species and stage of copepod added to the experimental incubation bottles 


\begin{tabular}{|c|c|c|c|c|c|c|c|c|c|c|c|c|c|c|}
\hline Bioassay & $\begin{array}{l}\text { Mixed } \\
\text { layer } \mathrm{T} \\
\left({ }^{\circ} \mathrm{C}\right)\end{array}$ & $\begin{array}{l}\text { Mixed } \\
\text { layer } \\
\text { salinity }\end{array}$ & $\begin{array}{l}\mathrm{NO}_{3}+\mathrm{NO}_{2} \\
\mu \mathrm{mol} \mathrm{L}\end{array}$ & $\begin{array}{l}\mathrm{Si} \mu \mathrm{M} \\
\mathrm{L}^{-1}\end{array}$ & $\begin{array}{l}\mathrm{PO}_{4} \\
\mu \mathrm{mol} \\
\mathrm{L}^{-1}\end{array}$ & $\begin{array}{l}{\left[\mathrm{NH}_{4}^{+}\right]} \\
\mathrm{nmol} \mathrm{L}^{-1}\end{array}$ & $\begin{array}{l}\mathrm{N}: \mathrm{P} \\
\text { (atomic } \\
\text { ratio) }\end{array}$ & $\begin{array}{l}\mathrm{TA} \\
(\mu \mathrm{mol} \\
\left.\mathrm{kg}^{-1}\right)\end{array}$ & $\begin{array}{l}\text { DIC } \\
(\mu \mathrm{mol} \\
\left.\mathrm{kg}^{-1}\right)\end{array}$ & $\mathrm{pH}$ & $\begin{array}{l}\mathrm{pCO}_{2} \\
(\mu \mathrm{atm})\end{array}$ & $\begin{array}{l}\text { TEP ( } \mu \mathrm{g} \\
\mathrm{L}^{-1} \\
\text { xanthan } \\
\text { equiv.) }\end{array}$ & $\begin{array}{l}\text { Total bacteria } \\
\left(\text { cell } \mathrm{ml}^{-1}\right)\end{array}$ & $\begin{array}{l}\text { Total } \\
\text { nannoplankt. } \\
\left(\text { cells } \mathrm{mL}^{-1} \text { ) }\right.\end{array}$ \\
\hline E01 271 & $\begin{array}{l}10.700 \\
(0.071)\end{array}$ & $\begin{array}{l}35.100 \\
(0.000)\end{array}$ & $\begin{array}{l}0.043 \\
(0.006)\end{array}$ & $\begin{array}{l}1.351 \\
(0.006)\end{array}$ & $\begin{array}{l}0.077 \\
(0.012)\end{array}$ & $\begin{array}{l}2.974 \\
(1.030)\end{array}$ & 0.604 & $\begin{array}{l}2325.300 \\
(0.436)\end{array}$ & $\begin{array}{l}2082.267 \\
(0.503)\end{array}$ & $\begin{array}{l}8.153 \\
(0.000)\end{array}$ & $\begin{array}{l}300.452 \\
(0.365)\end{array}$ & $\begin{array}{l}176.570 \\
(16.717)\end{array}$ & $\begin{array}{l}806803.712 \\
(41963.039)\end{array}$ & $\begin{array}{l}5444.164 \\
(341.646)\end{array}$ \\
\hline E03 271 & $\begin{array}{l}1.880 \\
(0.795)\end{array}$ & $\begin{array}{l}34.920 \\
(0.045)\end{array}$ & $\begin{array}{l}9.253 \\
(0.051)\end{array}$ & $\begin{array}{l}5.821 \\
(0.025)\end{array}$ & $\begin{array}{l}0.650 \\
(0.000)\end{array}$ & $\begin{array}{l}111.437 \\
(134.775)\end{array}$ & 14.407 & $\begin{array}{l}2305.267 \\
(6.529)\end{array}$ & $\begin{array}{l}2130.000 \\
(3.205)\end{array}$ & $\begin{array}{l}8.159 \\
(0.014)\end{array}$ & $\begin{array}{l}289.287 \\
(9.705)\end{array}$ & $\begin{array}{l}99.037 \\
(10.046)\end{array}$ & $\begin{array}{l}1173950.914 \\
(14221.856)\end{array}$ & $\begin{array}{l}41275.690 \\
(2242.764)\end{array}$ \\
\hline E04 271 & $\begin{array}{l}-1.575 \\
(0.050)\end{array}$ & $\begin{array}{l}32.625 \\
(0.050)\end{array}$ & $\begin{array}{l}4.200 \\
(0.156)\end{array}$ & $\begin{array}{l}12.214 \\
(0.023)\end{array}$ & $\begin{array}{l}0.790 \\
(0.000)\end{array}$ & 145.211 & 5.500 & $\begin{array}{l}2234.567 \\
(2.901)\end{array}$ & $\begin{array}{l}2106.400 \\
(5.671)\end{array}$ & $\begin{array}{l}8.129 \\
(0.009)\end{array}$ & $\begin{array}{l}304.682 \\
(7.219)\end{array}$ & $\begin{array}{l}90.973 \\
(6.804)\end{array}$ & $\begin{array}{l}460466.414 \\
(85179.903)\end{array}$ & $\begin{array}{l}3839.254 \\
(629.680)\end{array}$ \\
\hline E05 271 & $\begin{array}{l}6.450 \\
(0.058)\end{array}$ & $\begin{array}{l}35.000 \\
(0.000)\end{array}$ & $\begin{array}{l}5.380 \\
(0.544)\end{array}$ & $\begin{array}{l}3.867 \\
(0.151)\end{array}$ & $\begin{array}{l}0.437 \\
(0.025)\end{array}$ & $\begin{array}{l}162.527 \\
(162.836)\end{array}$ & 12.693 & $\begin{array}{l}2314.050 \\
(4.031)\end{array}$ & $\begin{array}{l}2108.700 \\
(2.022)\end{array}$ & $\begin{array}{l}8.146 \\
(0.003)\end{array}$ & $\begin{array}{l}304.295 \\
(2.154)\end{array}$ & $\begin{array}{l}111.855 \\
(11.460)\end{array}$ & $\begin{array}{l}1135333.889 \\
(152872.784)\end{array}$ & $\begin{array}{l}12071.861 \\
(1273.412)\end{array}$ \\
\hline E03 274 & $\begin{array}{l}2.224 \\
(0.021)\end{array}$ & $\begin{array}{l}33.932 \\
(0.002)\end{array}$ & $\begin{array}{l}24.080 \\
(0.252)\end{array}$ & $\begin{array}{l}19.393 \\
(0.095)\end{array}$ & $\begin{array}{l}1.597 \\
(0.006)\end{array}$ & $\begin{array}{l}812.623 \\
(70.177)\end{array}$ & 15.590 & 2287.800 & $\begin{array}{l}2152.342 \\
(6.112)\end{array}$ & 8.050 & 384 & $\begin{array}{l}3.293 \\
(1.678)\end{array}$ & $\begin{array}{l}653401.452 \\
(26549.817)\end{array}$ & $\begin{array}{l}4358.355 \\
(623.205)\end{array}$ \\
\hline E04 274 & $\begin{array}{l}0.400 \\
(0.037)\end{array}$ & $\begin{array}{l}33.706 \\
(0.005)\end{array}$ & $\begin{array}{l}18.537 \\
(0.605)\end{array}$ & $\begin{array}{l}71.310 \\
(0.473)\end{array}$ & $\begin{array}{l}1.190 \\
(0.046)\end{array}$ & $\begin{array}{l}519.415 \\
(308.750)\end{array}$ & 16.014 & 2293.000 & $\begin{array}{l}2129.500 \\
(4.355)\end{array}$ & 8.167 & 283 & $\begin{array}{l}65.473 \\
(2.887)\end{array}$ & $\begin{array}{l}804153.919 \\
(79884.942)\end{array}$ & $\begin{array}{l}1476.402 \\
(404.310)\end{array}$ \\
\hline
\end{tabular}

Table 2: Starting conditions for experimental incubations. Values represent averages, while (SD) is included where more than 3 measurements were made. 


\begin{tabular}{|c|c|c|c|c|c|}
\hline \multicolumn{2}{|c|}{ Experiment/incubation } & $C(\mu g)$ & $\mathrm{H}(\mu \mathrm{g})$ & $N(\mu g)$ & $\begin{array}{c}\mathrm{C}: \mathrm{N} \text { (mass } \\
\text { ratio) }\end{array}$ \\
\hline \multicolumn{6}{|c|}{ E03 271} \\
\hline \multicolumn{2}{|c|}{ T0 population } & $2228.53(1033.07)$ & $343.91(154.36)$ & $290.24(97.60)$ & $7.38(1.44)$ \\
\hline \multirow[t]{2}{*}{ Ambient } & $24 \mathrm{~h}$ & $2370.11(718.46)$ & 378.04 (104.09) & $284.68(50.08)$ & $8.19(1.51)$ \\
\hline & $96 \mathrm{~h}$ & $2944.47(603.86)$ & 464.80 (121.29) & $330.63(54.75)$ & $8.86(0.56)$ \\
\hline \multirow[t]{2}{*}{$750 \mu$ atm } & $24 \mathrm{~h}$ & $2460.75(775.92)$ & 358.65 (123.53) & $296.81(60.40)$ & $8.15(1.06)$ \\
\hline & $96 \mathrm{~h}$ & $2563.23(595.72)$ & $425.49(99.41)$ & $287.04(51.66)$ & $8.86(0.59)$ \\
\hline \multirow[t]{2}{*}{$1000 \mu \mathrm{atm}$} & $24 \mathrm{~h}$ & $1814.57(623.17)$ & $268.11(62.74)$ & $259.23(88.34)$ & $7.07(1.40)$ \\
\hline & $96 \mathrm{~h}$ & 2513.16 (738.55) & $393.35(120.84)$ & $288.09(63.67)$ & $8.60(0.85)$ \\
\hline \multicolumn{6}{|c|}{ E04 271} \\
\hline \multicolumn{2}{|c|}{ T0 population } & $1000.20(520.57)$ & $161.43(83.04)$ & $167.72(49.15)$ & $5.70(1.47)$ \\
\hline \multirow[t]{2}{*}{ Ambient } & $24 \mathrm{~h}$ & $1211.67(346.37)$ & $197.27(55.64)$ & $176.69(30.51)$ & $6.75(1.04)$ \\
\hline & $96 \mathrm{~h}$ & 1454.91 (968.46) & $190.75(86.75)$ & $195.59(94.16)$ & $7.06(2.09)$ \\
\hline \multirow[t]{2}{*}{$750 \mu \mathrm{atm}$} & $24 \mathrm{~h}$ & $908.51(343.28)$ & $149.38(56.26)$ & $161.69(39.02)$ & $5.55(1.25)$ \\
\hline & $96 \mathrm{~h}$ & 1330.19 (389.65) & $216.62(63.42)$ & $191.71(40.46)$ & $6.85(1.08)$ \\
\hline \multirow[t]{2}{*}{$1000 \mu \mathrm{atm}$} & $24 \mathrm{~h}$ & $872.04(237.25)$ & $140.82(38.32)$ & $150.84(32.41)$ & $5.75(0.90)$ \\
\hline & $96 \mathrm{~h}$ & $1066.25(882.90)$ & $177.15(144.76)$ & $184.06(73.86)$ & $5.17(2.05)$ \\
\hline \multicolumn{6}{|c|}{ E05 271} \\
\hline \multicolumn{2}{|c|}{ T0 population } & $74.06(18.73)$ & $10.83(3.01)$ & $17.92(3.70)$ & $4.15(0.68)$ \\
\hline \multirow[t]{2}{*}{ Ambient } & $24 \mathrm{~h}$ & $65.28(22.50)$ & $7.04(3.14)$ & $9.63(5.01)$ & $7.59(2.07)$ \\
\hline & $96 \mathrm{~h}$ & $66.01(26.04)$ & $7.25(3.74)$ & $11.76(5.33)$ & $6.37(2.77)$ \\
\hline \multirow[t]{2}{*}{$750 \mu \mathrm{atm}$} & $24 \mathrm{~h}$ & $71.28(35.02)$ & $8.25(4.41)$ & $11.15(4.74)$ & $6.97(3.13)$ \\
\hline & $96 \mathrm{~h}$ & $68.60(36.65)$ & $7.40(4.92)$ & $12.31(5.93)$ & $5.57(1.68)$ \\
\hline \multirow[t]{2}{*}{$1000 \mu \mathrm{atm}$} & $24 \mathrm{~h}$ & $69.61(35.78)$ & $7.75(4.68)$ & $13.74(5.14)$ & $4.97(1.21)$ \\
\hline & $96 \mathrm{~h}$ & $66.98(25.27)$ & $7.30(3.52)$ & $11.92(3.50)$ & $5.66(1.43)$ \\
\hline \multicolumn{6}{|c|}{ E03 274} \\
\hline \multicolumn{2}{|c|}{ T0 population } & $54.80(12.20)$ & $9.61(2.21)$ & $17.85(3.26)$ & $3.05(0.21)$ \\
\hline \multirow[t]{2}{*}{ Ambient } & $24 \mathrm{~h}$ & $66.75(23.67)$ & $9.76(3.38)$ & $18.32(4.56)$ & $3.57(0.69)$ \\
\hline & $96 \mathrm{~h}$ & $50.75(29.74)$ & $6.90(4.30)$ & $14.56(5.74)$ & $3.32(0.59)$ \\
\hline \multirow[t]{2}{*}{$750 \mu \mathrm{atm}$} & $24 \mathrm{~h}$ & $45.33(17.59)$ & $6.63(2.53)$ & $14.59(3.49)$ & $3.03(0.58)$ \\
\hline & $96 \mathrm{~h}$ & $37.66(14.32)$ & $5.35(2.14)$ & $12.43(4.48)$ & $3.29(1.58)$ \\
\hline \multirow[t]{2}{*}{$1000 \mu \mathrm{atm}$} & $24 \mathrm{~h}$ & $52.16(21.87)$ & 7.33 (3.28) & $15.55(4.96)$ & $3.30(0.50)$ \\
\hline & $96 \mathrm{~h}$ & $44.49(21.68)$ & $6.23(3.04)$ & $13.79(4.76)$ & $3.16(0.69)$ \\
\hline \multicolumn{6}{|c|}{ E04 274} \\
\hline \multicolumn{2}{|c|}{ T0 population } & 256.57 (128.63) & $46.51(21.76)$ & $45.02(14.77)$ & $5.45(1.06)$ \\
\hline \multirow[t]{2}{*}{ Ambient } & $24 \mathrm{~h}$ & $286.53(188.66)$ & $45.50(30.36)$ & $47.34(20.72)$ & $5.63(1.63)$ \\
\hline & $96 \mathrm{~h}$ & 222.33 (158.99) & $35.08(28.00)$ & 38.39 (18.41) & $5.38(1.61)$ \\
\hline \multirow[t]{2}{*}{ 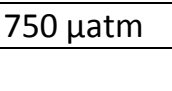 } & $24 \mathrm{~h}$ & $250.58(152.42)$ & 43.55 (29.73) & $41.98(18.13)$ & $5.61(1.59)$ \\
\hline & $96 \mathrm{~h}$ & $218.71(160.44)$ & 34.64 (30.97) & $35.56(21.39)$ & 6.09 (1.78) \\
\hline \multirow[t]{2}{*}{$1000 \mu \mathrm{atm}$} & $24 \mathrm{~h}$ & 260.74 (153.65) & $43.36(30.60)$ & $44.10(16.74)$ & $5.78(1.81)$ \\
\hline & $96 \mathrm{~h}$ & 218.09 (192.69) & $37.14(40.93)$ & $38.43(18.88)$ & $4.98(1.98)$ \\
\hline
\end{tabular}

Table 3: Average (SD) elemental composition of copepods either at time zero (T0) or after $24 \mathrm{~h}$ or 96 $\mathrm{h}$ of incubation at ambient or elevated $p \mathrm{CO}_{2}$ conditions. All copepods were stage $\mathrm{CV}$ with the exception of EO4 274 where a combination of $\mathrm{CV}$ and females were used. 


\begin{tabular}{|c|c|c|c|c|c|c|c|c|}
\hline \multirow[t]{2}{*}{ Bioassay } & \multirow{2}{*}{$\begin{array}{l}\text { TO TEP ( } \mu \mathrm{g} \\
\text { xanthan equiv. } \\
\left.\mathrm{L}^{-1}\right)[\mathrm{SD}]\end{array}$} & \multirow{2}{*}{$\begin{array}{l}\text { Bottle effects } \\
\triangle T E P ~^{-1}\end{array}$} & \multicolumn{4}{|c|}{ Treatment effects } & \multicolumn{2}{|c|}{ Copepod effects } \\
\hline & & & $24 \mathrm{~h}(750)$ & $24 \mathrm{~h} \mathrm{(1000)}$ & $96 \mathrm{~h}(750)$ & $96 \mathrm{~h} \mathrm{(1000)}$ & $24 \mathrm{~h}$ & $96 \mathrm{~h}$ \\
\hline $\begin{array}{l}\text { JR271 } \\
\text { (E01) }\end{array}$ & 176.6 [16.7] & 0.6677 & $\leftrightarrow$ & $\leftrightarrow$ & $\uparrow$ & $\uparrow$ & $\leftrightarrow$ & $\uparrow$ \\
\hline $\begin{array}{l}\text { JR271 } \\
\text { (E03) }\end{array}$ & 99.0 [10.0] & 1.0553 & $\leftrightarrow$ & $\leftrightarrow$ & $\leftrightarrow$ & $\leftrightarrow$ & $\leftrightarrow$ & $\uparrow$ \\
\hline $\begin{array}{l}\text { JR271 } \\
\text { (E04) }\end{array}$ & \begin{tabular}{|l|}
91.0 [6.98] \\
\end{tabular} & 5.8465 & $\leftrightarrow$ & $\leftrightarrow$ & $\leftrightarrow$ & $\uparrow$ & $\leftrightarrow$ & $\downarrow$ \\
\hline $\begin{array}{l}J R 271 \\
\text { (E05) }\end{array}$ & 111.9 (11.5] & 1.6261 & $\leftrightarrow$ & $\leftrightarrow$ & $\leftrightarrow$ & $\uparrow$ & $\leftrightarrow$ & 个 \\
\hline $\begin{array}{l}\text { JR274 } \\
\text { (E03) }\end{array}$ & $3.3[1.7)$ & 0.1004 & $\leftrightarrow$ & $\leftrightarrow$ & $\leftrightarrow$ & $\downarrow$ & $\leftrightarrow$ & $\uparrow$ \\
\hline $\begin{array}{l}\text { JR274 } \\
\text { (E04) }\end{array}$ & $65.5[2.9]$ & 0.4496 & $\leftrightarrow$ & $\uparrow$ & $\uparrow$ & $\uparrow$ & $\leftrightarrow$ & $\leftrightarrow$ \\
\hline
\end{tabular}

Table 4: Average concentrations [SD] of transparent exopolymeric particles (TEP) at the start of the incubation experiments (T0). Bottle effects were calculated as $\left(\mathrm{TEP}_{96 \mathrm{~h} \text {, ambient, non-copepod }}-\mathrm{TEP}_{\mathrm{TO}}\right) / 96$ and represent the rate of increase of TEP over the maximum duration of the experiments $(96 \mathrm{~h})$ in the control incubations (ambient, non-copepod). Treatment effects were determined through performing a 1-way ANOVA comparing concentrations of TEP in incubations with elevated levels of $p \mathrm{CO}_{2}$ with those of ambient conditions. All of incubations in this test contained copepods. Copepod effects were determined through performing a t-test comparing concentrations of TEP in incubations containing copepods with those without copepods. $\downarrow$ denotes significantly lower concentrations of TEP $(P<0.05)$, $\uparrow$ significantly higher TEP $(P<0.05)$ and $\leftrightarrow$ no significant difference in TEP. 


\begin{tabular}{|c|c|c|c|c|c|c|c|}
\hline Bioassay & T0 Cells & Bottle & Copepod & Treatn & ent effects & & \\
\hline $\begin{array}{l}\text { Phytoplankton } \\
\text { group }\left(P h y_{x}\right)\end{array}$ & & effects & effects & With o & opepods & $\begin{array}{l}\text { Withou } \\
\text { copepo }\end{array}$ & \\
\hline & & & & 750 & 1000 & 750 & 1000 \\
\hline & & & 1271 & & & & \\
\hline Diatoms & 282.65 & + & + & - & - & + & + \\
\hline Dinoflagellates & 7.37 & + & + & - & - & + & + \\
\hline Ciliates & 0.35 & + & + & - & - & + & + \\
\hline Flagellates & 0.27 & +++ & + & - & - & + & + \\
\hline & & & 3271 & & & & \\
\hline Diatoms & 5.19 & - & - & ++ & ++ & + & + \\
\hline Dinoflagellates & 13.01 & + & + & - & - & + & + \\
\hline Ciliates & 3.84 & - & + & + & - & - & + \\
\hline Flagellates & 0.84 & +++ & + & + & + & - & - \\
\hline & & & 4271 & & & & \\
\hline Diatoms & 249.96 & ++ & - & - & + & - & - \\
\hline Dinoflagellates & 9.54 & ++ & + & - & - & + & 0 \\
\hline Ciliates & 1.35 & 0 & - & - & - & + & + \\
\hline Flagellates & 0.68 & ++ & + & - & - & + & + \\
\hline & & & 25271 & & & & \\
\hline Diatoms & 0.77 & ++ & - & - & - & 0 & 0 \\
\hline Dinoflagellates & 27.4 & + & - & - & - & - & - \\
\hline Ciliates & 0.08 & + & -- & ++ & + & + & - \\
\hline Flagellates & 0 & 0 & + & - & - & - & + \\
\hline & & & 3274 & & & & \\
\hline Diatoms & 14.03 & ++ & - & + & + & - & - \\
\hline Dinoflagellates & 4.41 & - & + & - & - & +++ & +++ \\
\hline Ciliates & 0.85 & ++ & + & + & + & - & + \\
\hline Flagellates & 0.22 & + & + & - & - & - & + \\
\hline & & & 24274 & & & & \\
\hline Diatoms & 1084.44 & - & + & - & 0 & + & - \\
\hline Dinoflagellates & 8.22 & - & - & - & - & 0 & + \\
\hline Ciliates & 28.25 & - & + & - & - & + & - \\
\hline Flagellates & 1.64 & + & -- & - & - & - & - \\
\hline
\end{tabular}

Table 5: Concentrations (cells $\mathrm{mL}^{-1}$ ) of the four major phytoplankton groups $\left(P h y_{x}\right)$ in each of the experimental incubations. Bottle effects were calculated as $\left(P h y_{\mathrm{x}, \mathrm{TO}}-P h y_{\mathrm{x}, \text { ambient, non-copepods }}\right) / P h y_{\mathrm{x}, \mathrm{T} 0}$, Copepods effects as (Phy $\left.\mathrm{x}_{\mathrm{x}, \text { ambient, copepods }}-\mathrm{Phy}_{\mathrm{x}, \text { treatment, copepods }}\right) /$ Phy $\mathrm{y}_{\mathrm{x}, \mathrm{ambient}}$ copepods and Treatment effects as $\left(P h y_{x, \text { copepods }}-P h y_{x, \text { non-copepods }}\right) / P h y_{\mathrm{x}, \text { copepods. }}$ ' 0 ' represents fold changes of between -0.05 to +0.05 ; ' + ' or ' - ', up to a 1 fold increase; ' ++ ' $^{\prime}$ or '--', a 1 to 5 fold increase; ' +++ ' $^{\prime}$ or '---', a more than 5 fold increase. 


\section{Figure Legends}

Fig. 1: Proportion and total cell concentration (cells $\mathrm{mL}^{-1}$ ) of the four major phytoplankton taxa at the start of each of the six incubation experiments (TO).

Fig. 2: Carbon to nitrogen mass ratio $(\mathrm{C}: \mathrm{N})$ of a subset of the selected grazing copepods at the start of the incubation experiments (TO). The species/stages of the selected copepod grazers for each experiment are listed in Table 1. Specimens from Station E01 271 were not analysed as a result of a processing error.

Fig. 3: Concentration of total bacterial cells $\left(\right.$ cell $\mathrm{mL}^{-1}$ ) at the start of each incubation experiment (T0) and in each of the three treatments (ambient, $750 \mu$ atm $p \mathrm{CO}_{2}$ and $1000 \mu \mathrm{atm} p \mathrm{CO}_{2}$ ). Open circle denotes average concentration within incubations with copepods, filled circles, without copepods. Bars represent $95 \%$ confidence intervals of incubations containing copepods. Instances where the filled circles fell outside these confidence intervals indicate significant differences between concentrations in copepod versus non-copepod incubations.

Fig. 4: Concentration of total nannoplankton cells (cell $\mathrm{mL}^{-1}$ ) at the start of each incubation experiment (TO) and in each of the three treatments (ambient, $750 \mu \mathrm{atm} p \mathrm{CO}_{2}$ and $1000 \mu \mathrm{atm} p \mathrm{CO}_{2}$ ). Open circle denotes average concentration of incubations with copepods, filled circles, without copepods. Bars represent $95 \%$ confidence intervals of incubations containing copepods. Instances where the filled circles fell outside of these confidence intervals indicate significant differences between concentrations in copepod versus non-copepod incubations.

Fig. 5: Relative change in bacterial cell concentrations in relation to the relative change in the concentration of transparent exopolymeric particles (TEP) across all six incubation experiments. Dashed lines represent trends fitted through least-squared regression. None of the trends were statistically significant. 
Fig. 6: Relative change in nannoplankton cell concentrations in relation to the relative change in the concentration of transparent exopolymeric particles (TEP) across all six incubation experiments. Dashed lines represent trends fitted through least-squared regression. None of the trends were statistically significant.

Fig. 7: Relative response level of the four major phytoplankton taxa to treatments relative to that observed in incubations in ambient conditions. Response levels were graded as between 0 and 3 for each incubation experiment, as detailed in Table $1 .{ }^{*}$ indicates a significant difference between incubations with copepods and those without copepods (paired t-test, $\mathrm{P}<0.05$ ).

Fig. 8: Carbon to nitrogen mass ratio $(\mathrm{C}: \mathrm{N})$ of the selected copepod grazers either at the start of the incubation experiments (TO) or at their completion. The species/stages of the selected copepod grazers for each experiment are listed in Table 1. Specimens from Station E01 271 were not analysed as a result of a processing error. ${ }^{*}$ indicates a significant difference to the starting population (1-way ANOVA, $\mathrm{P}<0.05)$. 
Appendix 1: Parameter measurements on completion of the experimental incubations in ambient conditions. Starting conditions are given in Table 2.

\begin{tabular}{|c|c|c|c|c|c|c|c|c|c|c|}
\hline Bioassay & Duration & Copepods & $\begin{array}{l}\mathrm{N}: \mathrm{P} \\
\text { (atomic } \\
\text { ratio) }\end{array}$ & $\begin{array}{l}\text { TA } \\
(\mu \mathrm{mol} \\
\left.\mathrm{kg}^{-1}\right)\end{array}$ & $\begin{array}{l}\text { DIC } \\
(\mu \mathrm{mol} \\
\left.\mathrm{kg}^{-1}\right)\end{array}$ & $\mathrm{pH}$ & $\begin{array}{l}p \mathrm{CO}_{2} \\
\text { ( } \mu \mathrm{atm})\end{array}$ & $\begin{array}{l}\text { Average } \\
(\mathrm{SD}) \mathrm{TEP} \\
\left(\mu \mathrm{g} \mathrm{L}{ }^{-1}\right. \\
\text { xanthan } \\
\text { equiv.) }\end{array}$ & $\begin{array}{l}\text { Average } \\
\text { (SD) total } \\
\text { bacteria } \\
\text { (cells } \mathrm{mL}^{-1} \text { ) }\end{array}$ & $\begin{array}{l}\text { Average } \\
\text { (SD) total } \\
\text { nannoflag. } \\
\text { (cells } \mathrm{mL}^{-1} \text { ) }\end{array}$ \\
\hline \multirow[t]{4}{*}{ E01 271} & 24 & Yes & 7.0 & 2322.5 & 2080.0 & 8.1 & 305.2 & $\begin{array}{l}149.5 \\
(7.0)\end{array}$ & $\begin{array}{l}922122.7 \\
(126373.0)\end{array}$ & $\begin{array}{l}6054.3 \\
(1548.3)\end{array}$ \\
\hline & 24 & No & 1.215 & 2316.8 & 2078.1 & 8.1 & 309.8 & $\begin{array}{l}143.3 \\
(9.8)\end{array}$ & 827276.1 & 5912.2 \\
\hline & 96 & Yes & 2.1 & 2309.1 & 2099.4 & 8.1 & 364.3 & $\begin{array}{l}135.2 \\
(10.6)\end{array}$ & & \\
\hline & 96 & No & 1.843 & 2306.1 & 2121.6 & 8.0 & 422.7 & $\begin{array}{l}244.4 \\
(37.0) \\
\end{array}$ & & \\
\hline \multirow[t]{4}{*}{ E03 271} & 24 & Yes & 18.2 & 2299.9 & 2146.9 & 8.1 & 348.4 & $\begin{array}{l}142.7 \\
(11.2)\end{array}$ & $\begin{array}{l}924927.7 \\
(26989.6) \\
\end{array}$ & $\begin{array}{l}43954.0 \\
(1680.8) \\
\end{array}$ \\
\hline & 24 & No & 14.403 & 2297.6 & 2132.2 & 8.1 & 322.0 & $\begin{array}{l}128.4 \\
(7.4) \\
\end{array}$ & 872248.4 & 40346.4 \\
\hline & 96 & Yes & 28.6 & 2299.4 & 2154.6 & 8.1 & 368.0 & $\begin{array}{l}223.9 \\
(11.2)\end{array}$ & & \\
\hline & 96 & No & 17.778 & 2301.4 & 2125.3 & 8.1 & 302.0 & $\begin{array}{l}200.3 \\
(2.8) \\
\end{array}$ & & \\
\hline \multirow[t]{4}{*}{ E04 271} & 24 & Yes & 5.9 & 2229.3 & 2120.9 & 8.0 & 386.7 & $\begin{array}{l}116.6 \\
(19.9)\end{array}$ & $\begin{array}{l}423270.3 \\
(5039.0)\end{array}$ & $\begin{array}{l}4470.2 \\
(114.5)\end{array}$ \\
\hline & 24 & No & 3.923 & 2225.5 & 2102.3 & 8.1 & 344.1 & $\begin{array}{l}142.0 \\
(15.8)\end{array}$ & 515806.7 & 4656.7 \\
\hline & 96 & Yes & 4.6 & 2228.9 & 2112.3 & 8.1 & 363.6 & $\begin{array}{l}192.9 \\
(26.1) \\
\end{array}$ & & \\
\hline & 96 & No & 0.236 & 2228.4 & 2028.8 & 8.3 & 195.2 & $\begin{array}{l}651.3 \\
(7.4) \\
\end{array}$ & & \\
\hline \multirow[t]{4}{*}{ E05 271} & 24 & Yes & 12.5 & 2309.1 & 2121.0 & 8.1 & 348.7 & $\begin{array}{l}145.1 \\
(8.1) \\
\end{array}$ & $\begin{array}{l}1380493.1 \\
(69973.4) \\
\end{array}$ & $\begin{array}{l}12950.0 \\
(2351.8) \\
\end{array}$ \\
\hline & 24 & No & 12.689 & 2311.5 & 2123.9 & 8.1 & 352.9 & $\begin{array}{l}160.0 \\
(9.8) \\
\end{array}$ & 1430876.3 & 14696.8 \\
\hline & 96 & Yes & 10.1 & 2313.5 & 2096.0 & 8.2 & 296.9 & $\begin{array}{l}145.1 \\
(3.7)\end{array}$ & & \\
\hline & 96 & No & 8.582 & 2307.7 & 2088.0 & 8.2 & 292.8 & $\begin{array}{l}268.0 \\
(35.4) \\
\end{array}$ & & \\
\hline \multirow[t]{4}{*}{ E03 274} & 24 & Yes & 15.4 & 2291.1 & 2142.7 & 8.1 & 342.0 & $\begin{array}{l}5.7 \\
(5.0) \\
\end{array}$ & $\begin{array}{l}673354.5 \\
(232254.2) \\
\end{array}$ & $\begin{array}{l}4476.0 \\
(217.1) \\
\end{array}$ \\
\hline & 24 & No & 15.300 & 2288.1 & 2138.1 & 8.1 & 337.0 & $\begin{array}{l}7.6 \\
(1.2)\end{array}$ & 361558.2 & 1527.6 \\
\hline & 96 & Yes & 16.0 & 2262.5 & 2130.9 & 8.1 & 374.0 & $\begin{array}{l}26.6 \\
(1.9)\end{array}$ & & \\
\hline & 96 & No & 15.808 & 2286.7 & 2138.4 & 8.1 & 339.0 & $\begin{array}{l}12.9 \\
(3.6)\end{array}$ & & \\
\hline \multirow[t]{4}{*}{ E04 274} & 24 & Yes & 15.7 & 2291.9 & 2113.1 & 8.2 & 259.0 & $\begin{array}{l}51.0 \\
(11.8) \\
\end{array}$ & $\begin{array}{l}1043846.7 \\
(28753.2) \\
\end{array}$ & $\begin{array}{l}3727.4 \\
(470.1) \\
\end{array}$ \\
\hline & 24 & No & 15.256 & 2293.7 & 2119.3 & 8.2 & 267.0 & $\begin{array}{l}37.9 \\
(21.4) \\
\end{array}$ & 1155703.6 & 4354.8 \\
\hline & 96 & Yes & 15.9 & 2296.5 & 2085.2 & 8.3 & 215.0 & $\begin{array}{l}82.1 \\
(12.2)\end{array}$ & & \\
\hline & 96 & No & 16.494 & NA & 2164.3 & NA & NA & $\begin{array}{l}108.6 \\
(25.6) \\
\end{array}$ & & \\
\hline
\end{tabular}


Appendix 2: Parameter measurements on completion of the experimental incubations in the 750 $\mu$ atm $p \mathrm{CO}_{2}$ treatments. Starting conditions are given in Table 2.

\begin{tabular}{|c|c|c|c|c|c|c|c|c|c|c|}
\hline Bioassay & Duration & Copepods & $\begin{array}{l}\mathrm{N}: \mathrm{P} \\
\text { (atomic } \\
\text { ratio) }\end{array}$ & $\begin{array}{l}\text { TA } \\
(\mu \mathrm{mol} \\
\left.\mathrm{kg}^{-1}\right)\end{array}$ & $\begin{array}{l}\text { DIC } \\
(\mu \mathrm{mol} \\
\left.\mathrm{kg}^{-1}\right)\end{array}$ & $\mathrm{pH}$ & $\begin{array}{l}p \mathrm{CO}_{2} \\
\text { ( } \mu \text { atm) }\end{array}$ & $\begin{array}{l}\text { Average } \\
(\mathrm{SD}) \mathrm{TEP} \\
\left(\mu \mathrm{g} \mathrm{L} \mathrm{L}^{-1}\right. \\
\text { gum } \\
\text { xanthan } \\
\text { equiv.) }\end{array}$ & $\begin{array}{l}\text { Average } \\
(\mathrm{SD}) \text { total } \\
\text { bacteria } \\
\left(\text { cells } \mathrm{mL}^{-1} \text { ) }\right.\end{array}$ & $\begin{array}{l}\text { Average } \\
(\mathrm{SD}) \text { total } \\
\text { nannoplankt. } \\
\left(\text { cells } \mathrm{mL}^{-1} \text { ) }\right.\end{array}$ \\
\hline \multirow[t]{4}{*}{ E01 271} & 24 & Yes & 2.9 & 2322.0 & 2199.3 & 7.9 & 625.3 & $\begin{array}{l}155.1 \\
(8.4)\end{array}$ & $\begin{array}{l}851978.2 \\
(253396.5)\end{array}$ & $\begin{array}{l}4011.9 \\
(3242.0)\end{array}$ \\
\hline & 24 & No & 2.0 & 2331.5 & 2207.0 & 7.9 & 620.6 & & 756796.9 & 5064.8 \\
\hline & 96 & Yes & 1.9 & 2333.5 & 2246.8 & 7.8 & 823.3 & $\begin{array}{l}153.2 \\
(7.5)\end{array}$ & & \\
\hline & 96 & No & 0.5 & 2328.8 & 2231.6 & 7.8 & 759.6 & & & \\
\hline \multirow[t]{4}{*}{ E03 271} & 24 & Yes & 15.9 & 2314.0 & 2258.4 & 7.8 & 722.9 & $\begin{array}{l}147.0 \\
(6.7)\end{array}$ & $\begin{array}{l}946909.8 \\
(41416.8) \\
\end{array}$ & $\begin{array}{l}45213.7 \\
(5527.9) \\
\end{array}$ \\
\hline & 24 & No & 15.4 & 2305.6 & 2235.6 & 7.8 & 640.9 & & 950633.5 & 43088.2 \\
\hline & 96 & Yes & 26.7 & 2308.1 & 2252.7 & 7.8 & 737.2 & $\begin{array}{l}259.9 \\
(20.7)\end{array}$ & & \\
\hline & 96 & No & 17.6 & 2306.2 & 2223.3 & 7.9 & 578.8 & & & \\
\hline \multirow[t]{4}{*}{ E04 271} & 24 & Yes & 7.0 & 2231.7 & 2206.3 & 7.7 & 781.8 & $\begin{array}{l}128.4 \\
(20.1)\end{array}$ & $\begin{array}{l}425599.1 \\
(10102.0)\end{array}$ & $\begin{array}{l}4869.8 \\
(949.0)\end{array}$ \\
\hline & 24 & No & 4.1 & 2232.1 & 2189.3 & 7.8 & 667.9 & & 474527.5 & 5157.9 \\
\hline & 96 & Yes & 5.5 & 2236.9 & 2197.9 & 7.8 & 706.5 & $\begin{array}{l}183.6 \\
(15.6) \\
\end{array}$ & & \\
\hline & 96 & No & 0.1 & NA & NA & NA & NA & & & \\
\hline \multirow[t]{4}{*}{ E05 271} & 24 & Yes & 12.4 & 2319.1 & 2226.3 & 7.8 & 664.2 & $\begin{array}{l}140.2 \\
(12.4)\end{array}$ & $\begin{array}{l}1364566.6 \\
(29206.0)\end{array}$ & $\begin{array}{l}12495.6 \\
(1920.1)\end{array}$ \\
\hline & 24 & No & 12.7 & 2309.3 & 2215.1 & 7.8 & 653.1 & & 1380145.0 & 15539.9 \\
\hline & 96 & Yes & 9.9 & 2316.4 & 2188.5 & 7.9 & 531.4 & $\begin{array}{l}170.0 \\
(12.1)\end{array}$ & & \\
\hline & 96 & No & 9.1 & 2319.1 & 2195.6 & 7.9 & 535.8 & & & \\
\hline \multirow[t]{4}{*}{ E03 274} & 24 & Yes & 15.2 & 2289.6 & 2180.9 & 8.0 & 451.0 & $\begin{array}{l}3.3 \\
(0.7)\end{array}$ & $\begin{array}{l}836115.7 \\
(19018.9) \\
\end{array}$ & $\begin{array}{l}2876.5 \\
(1717.3)\end{array}$ \\
\hline & 24 & No & 15.1 & 2291.8 & 2178.6 & 8.0 & 437.0 & & 830448.8 & 3355.0 \\
\hline & 96 & Yes & 15.9 & 2292.4 & 2174.3 & 8.0 & 420.0 & $\begin{array}{l}27.5 \\
(2.7)\end{array}$ & & \\
\hline & 96 & No & 15.8 & 2289.2 & 2177.6 & 8.0 & 440.0 & & & \\
\hline \multirow[t]{4}{*}{ E04 274} & 24 & Yes & 15.4 & 2293.4 & 2178.3 & 8.0 & 398.0 & $\begin{array}{l}49.0 \\
(5.7)\end{array}$ & $\begin{array}{l}1042692.9 \\
(39800.6) \\
\end{array}$ & $\begin{array}{l}3492.6 \\
(333.9) \\
\end{array}$ \\
\hline & 24 & No & 15.7 & 2296.0 & 2175.8 & 8.1 & 385.0 & & 1248353.9 & 3576.1 \\
\hline & 96 & Yes & 16.0 & 2298.0 & 2160.9 & 8.1 & 342.0 & $\begin{array}{l}155.6 \\
(9.5)\end{array}$ & & \\
\hline & 96 & No & 15.4 & 2296.4 & 2168.9 & 8.1 & 365.0 & 15.4 & & \\
\hline
\end{tabular}


Appendix 3: Parameter measurements on completion of the experimental incubations in the 1000 $\mu$ atm $p \mathrm{CO}_{2}$ treatments. Starting conditions are given in Table 2.

\begin{tabular}{|c|c|c|c|c|c|c|c|c|c|c|}
\hline Bioassay & Duration & Copepods & $\begin{array}{l}\mathrm{N}: \mathrm{P} \\
\text { (atomic } \\
\text { ratio) }\end{array}$ & $\begin{array}{l}\text { TA } \\
(\mu \mathrm{mol} \\
\left.\mathrm{kg}^{-1}\right)\end{array}$ & $\begin{array}{l}\mathrm{DIC} \\
(\mu \mathrm{mol} \\
\left.\mathrm{kg}^{-1}\right)\end{array}$ & $\mathrm{pH}$ & $\begin{array}{l}p \mathrm{CO}_{2} \\
\text { ( } \mu \text { atm) }\end{array}$ & $\begin{array}{l}\text { Average } \\
(\mathrm{SD}) \mathrm{TEP} \\
\text { ( } \mu \mathrm{g} \mathrm{L}^{-1} \\
\text { xanthan } \\
\text { equiv.) }\end{array}$ & $\begin{array}{l}\text { Average } \\
(\mathrm{SD}) \text { total } \\
\text { bacteria } \\
\left(\text { cells } \mathrm{mL}^{-1}\right)\end{array}$ & $\begin{array}{l}\text { Average } \\
(\mathrm{SD}) \text { total } \\
\text { nannoplankt. } \\
\left(\text { cells } \mathrm{mL}^{-1} \text { ) }\right.\end{array}$ \\
\hline \multirow[t]{4}{*}{ E01271 } & 24 & Yes & 2.0 & 2334.3 & 2224.6 & 7.8 & 688.8 & $\begin{array}{l}173.1 \\
(21.0)\end{array}$ & $\begin{array}{l}866416.6 \\
(180754.5)\end{array}$ & $\begin{array}{l}6313.0 \\
(545.4)\end{array}$ \\
\hline & 24 & No & 1.1 & 2342.3 & 2224.9 & 7.9 & 659.0 & & 534542.3 & 3207.0 \\
\hline & 96 & Yes & 2.8 & 2334.2 & 2263.9 & 7.7 & 943.8 & $\begin{array}{l}173.7 \\
(6.0)\end{array}$ & & \\
\hline & 96 & No & 1.0 & 2333.7 & 2253.1 & 7.7 & 866.5 & & & \\
\hline \multirow[t]{4}{*}{ E03 271} & 24 & Yes & 17.2 & 2312.2 & 2272.8 & 7.7 & 827.1 & $\begin{array}{l}130.9 \\
(4.3)\end{array}$ & $\begin{array}{l}950025.8 \\
(47509.0)\end{array}$ & $\begin{array}{l}47774.8 \\
(2671.6)\end{array}$ \\
\hline & 24 & No & 15.5 & 2310.8 & 2269.0 & 7.8 & 805.3 & & 921361.4 & 40506.9 \\
\hline & 96 & Yes & 23.0 & 2311.4 & 2299.2 & 7.7 & 1030.4 & $\begin{array}{l}208.4 \\
(19.7)\end{array}$ & & \\
\hline & 96 & No & 17.2 & 2314.9 & 2269.6 & 7.8 & 793.0 & & & \\
\hline \multirow[t]{4}{*}{ E04 271} & 24 & Yes & 7.2 & 2240.1 & 2231.5 & 7.7 & 910.3 & $\begin{array}{l}138.3 \\
(7.5) \\
\end{array}$ & $\begin{array}{l}449130.9 \\
(49422.8) \\
\end{array}$ & $\begin{array}{l}4965.5 \\
(470.7) \\
\end{array}$ \\
\hline & 24 & No & 4.1 & 2233.4 & 2212.6 & 7.7 & 810.1 & & 454930.6 & 4513.3 \\
\hline & 96 & Yes & 3.0 & 2236.1 & 2211.4 & 7.8 & 774.9 & $\begin{array}{l}377.7 \\
(33.1) \\
\end{array}$ & & \\
\hline & 96 & No & 0.1 & 2240.1 & 2148.4 & 8.0 & 417.8 & & & \\
\hline \multirow[t]{4}{*}{ E05 271} & 24 & Yes & 12.1 & 2320.5 & 2261.9 & 7.7 & 870.0 & $\begin{array}{l}151.3 \\
(13.5) \\
\end{array}$ & $\begin{array}{l}1363161.4 \\
(21832.2) \\
\end{array}$ & $\begin{array}{l}12451.0 \\
(1685.0)\end{array}$ \\
\hline & 24 & No & 12.9 & 2314.3 & 2247.2 & 7.8 & 807.1 & & 1243892.1 & 11405.5 \\
\hline & 96 & Yes & 10.1 & 2318.3 & 2234.5 & 7.8 & 716.7 & $\begin{array}{l}179.3 \\
(18.1)\end{array}$ & & \\
\hline & 96 & No & 1.0 & 2325.3 & 2209.9 & 7.9 & 577.5 & & & \\
\hline \multirow[t]{4}{*}{ E03 274} & 24 & Yes & 15.4 & 2295.2 & 2206.9 & 7.9 & 528.0 & $\begin{array}{l}5.0 \\
(1.1) \\
\end{array}$ & $\begin{array}{l}824785.6 \\
(18588.5) \\
\end{array}$ & $\begin{array}{l}2981.2 \\
(163.9) \\
\end{array}$ \\
\hline & 24 & No & 15.2 & 2296.9 & 2211.3 & 7.92 & 540 & & 481463.0 & 2800.4 \\
\hline & 96 & Yes & 16.0 & 2297.8 & 2210.6 & 8.0 & 493.0 & $\begin{array}{l}18.9 \\
(2.4)\end{array}$ & & \\
\hline & 96 & No & 16.1 & 2292.2 & 2201.4 & 7.93 & 516 & & & \\
\hline \multirow[t]{4}{*}{ E04 274} & 24 & Yes & 15.6 & 2294.1 & 2208.6 & 7.9 & 538.0 & $\begin{array}{l}70.5 \\
(2.9) \\
\end{array}$ & $\begin{array}{l}1060930.4 \\
(125832.4) \\
\end{array}$ & $\begin{array}{l}3279.4 \\
(228.2) \\
\end{array}$ \\
\hline & 24 & No & 15.3 & 2298.4 & 2203 & 7.98 & 463 & & 1043688.3 & 3384.3 \\
\hline & 96 & Yes & 16.1 & 2297.2 & 2199.0 & 8.0 & 453.0 & $\begin{array}{l}120.0 \\
(0.8) \\
\end{array}$ & & \\
\hline & 96 & No & 16.3 & 2303.3 & 2184.4 & 8.04 & 390 & & & \\
\hline
\end{tabular}




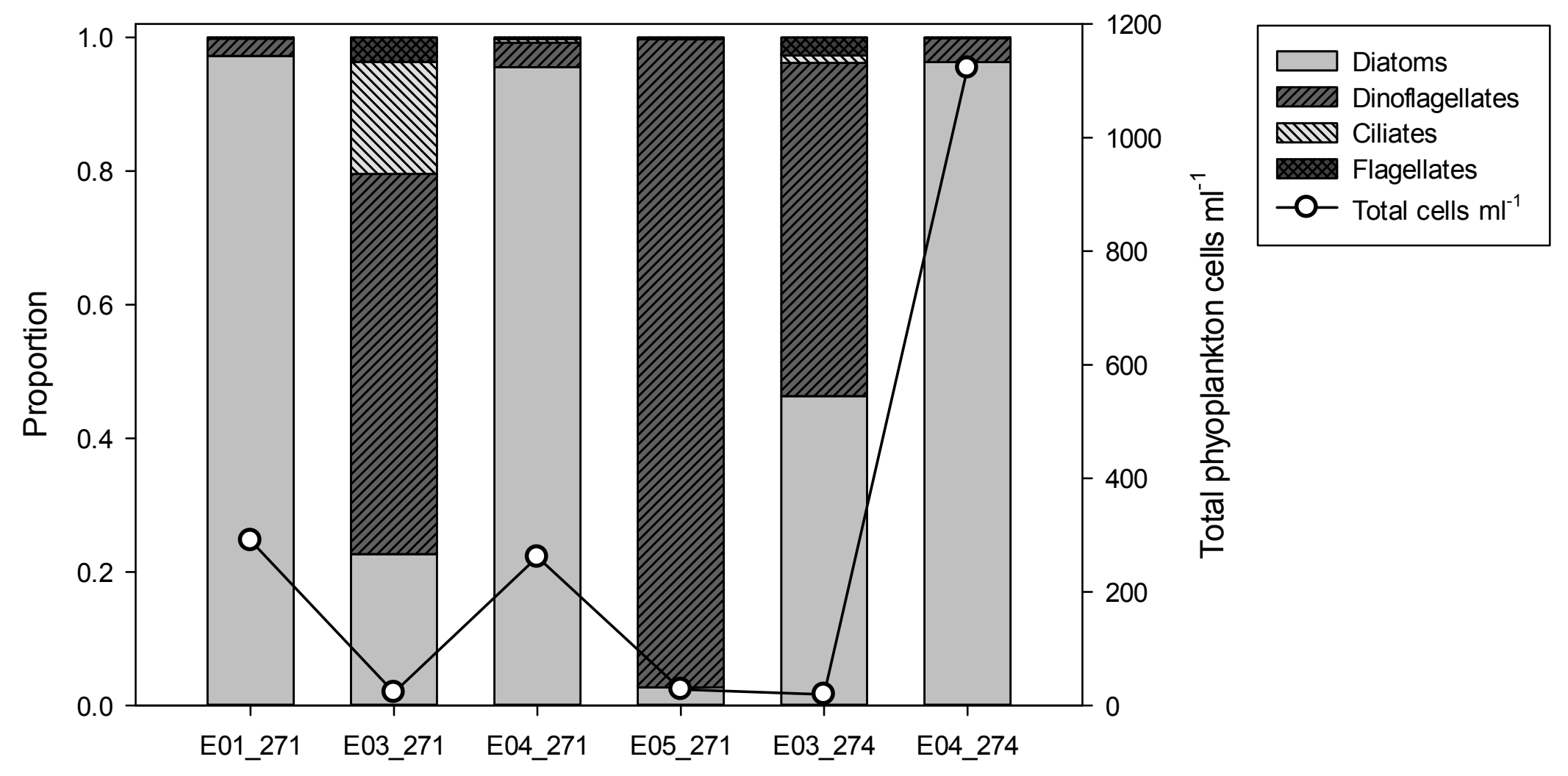

Fig. 1 


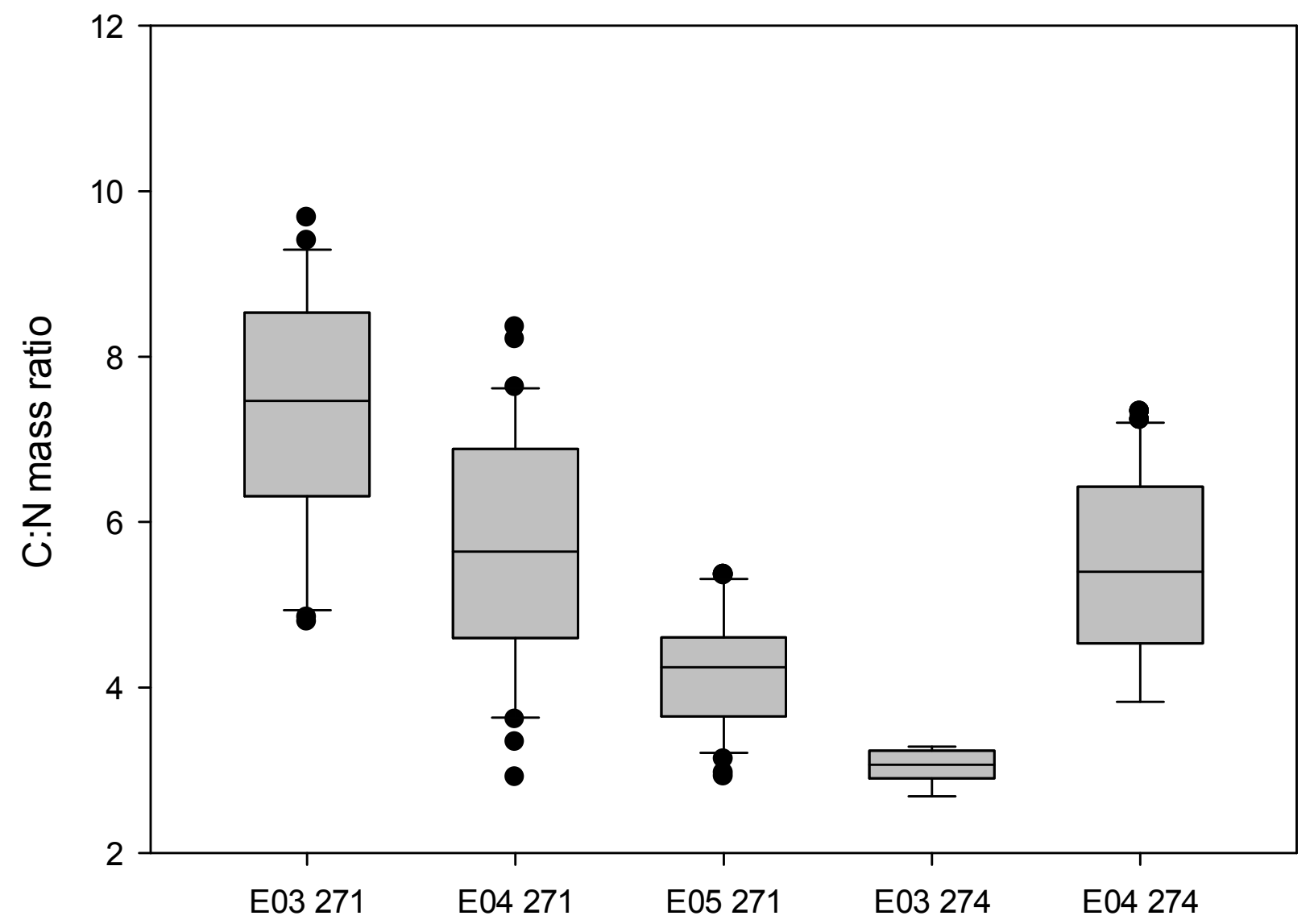

Fig. 2 

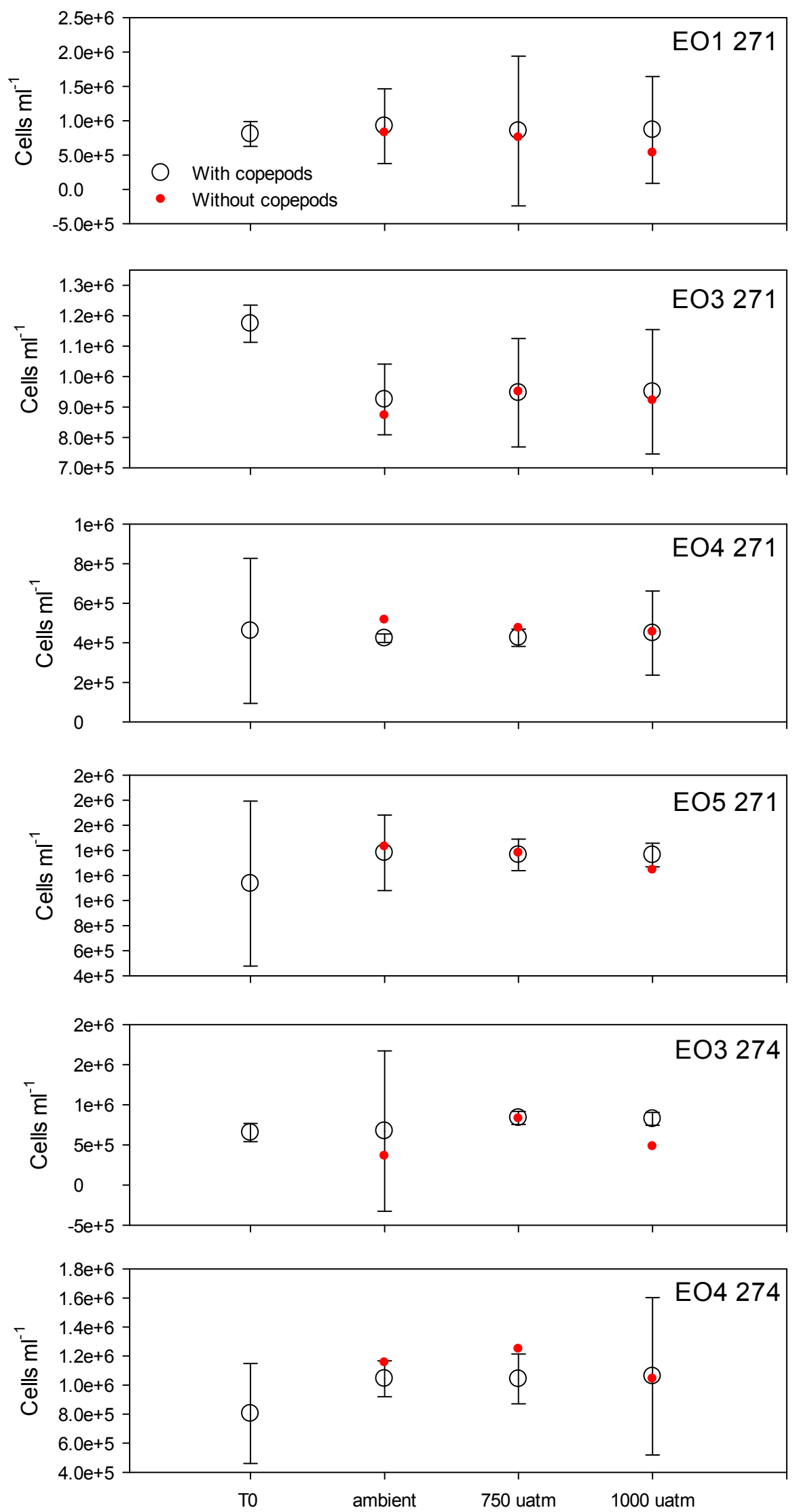

Fig. 3 

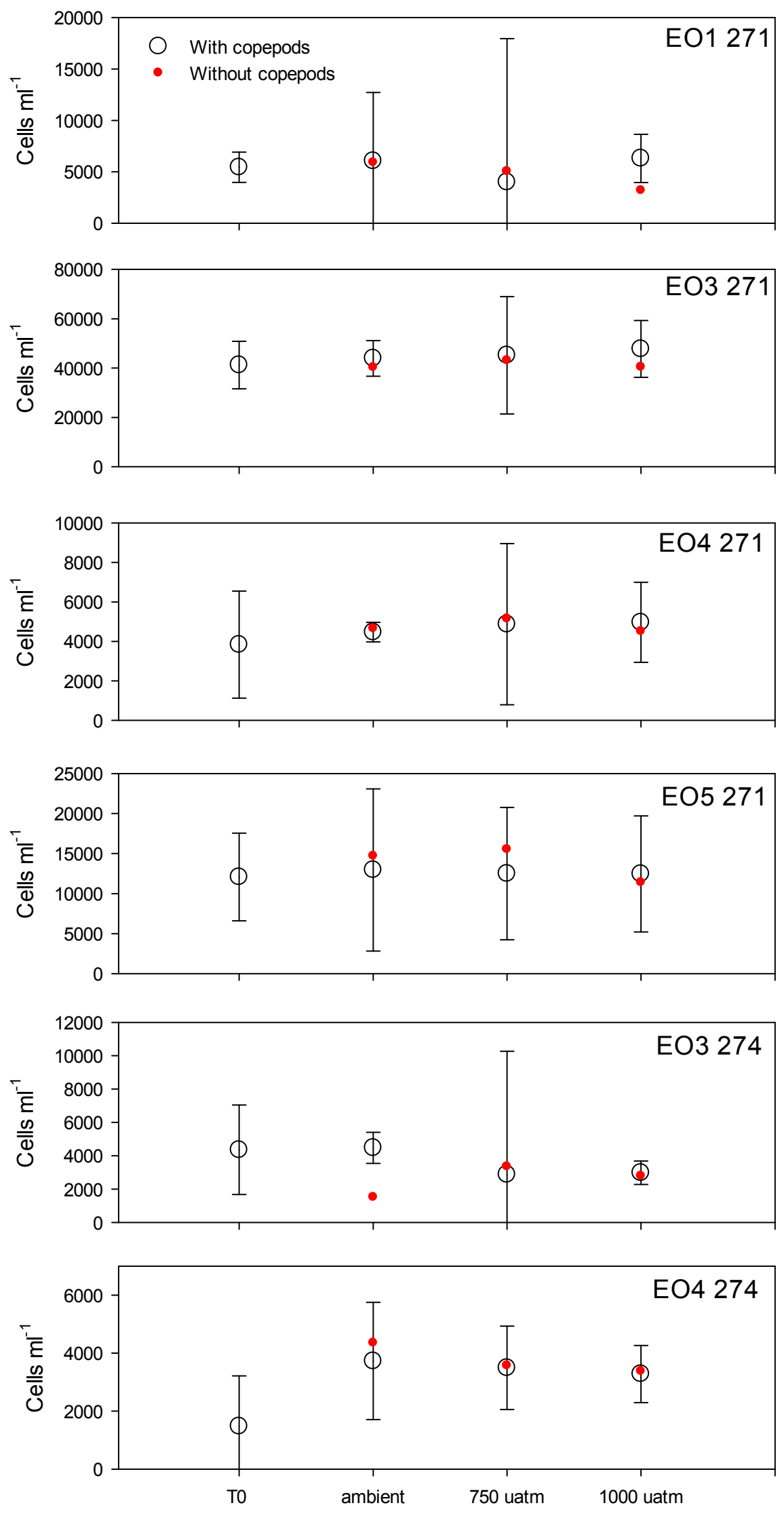

Fig. 4 

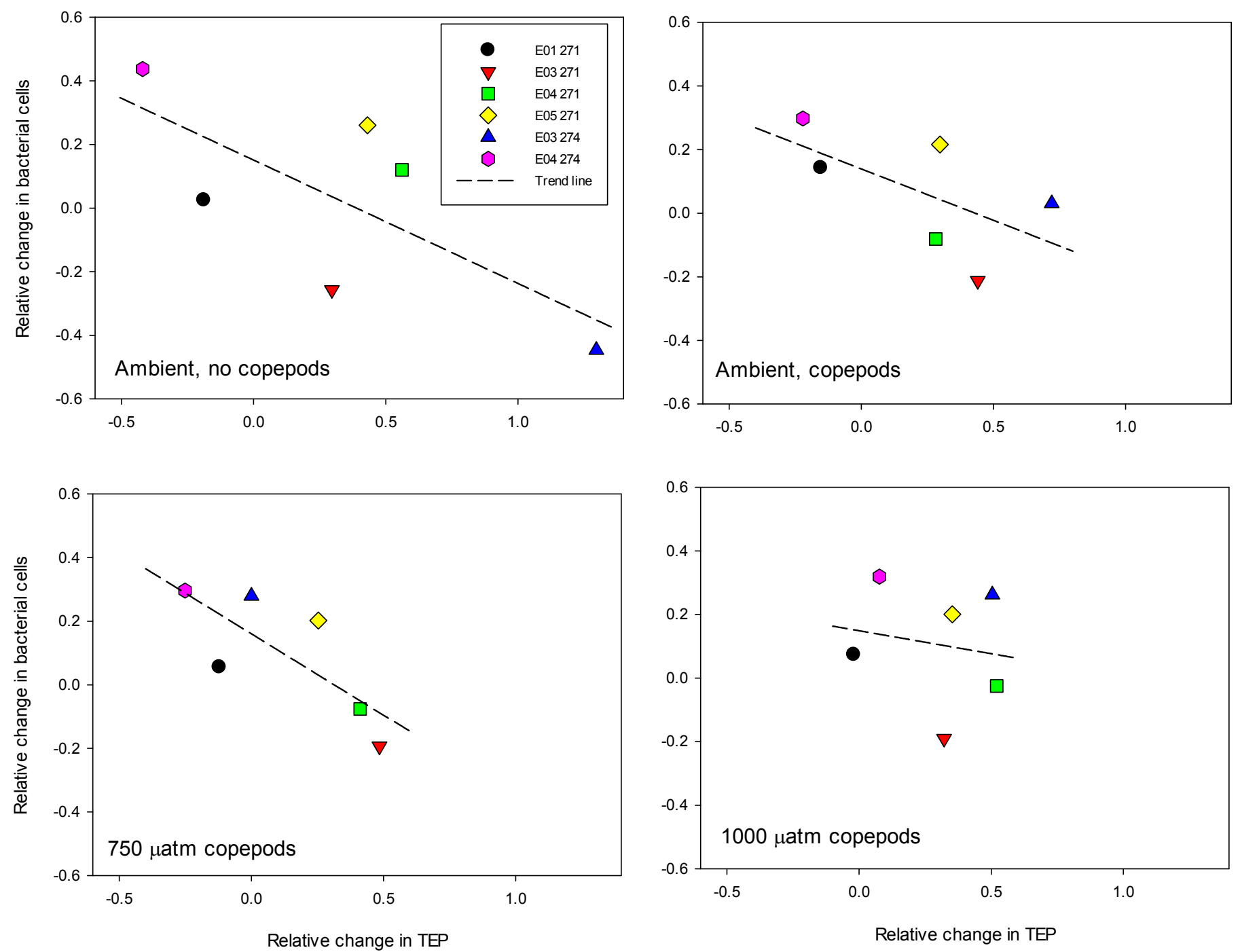

Fig. 5 

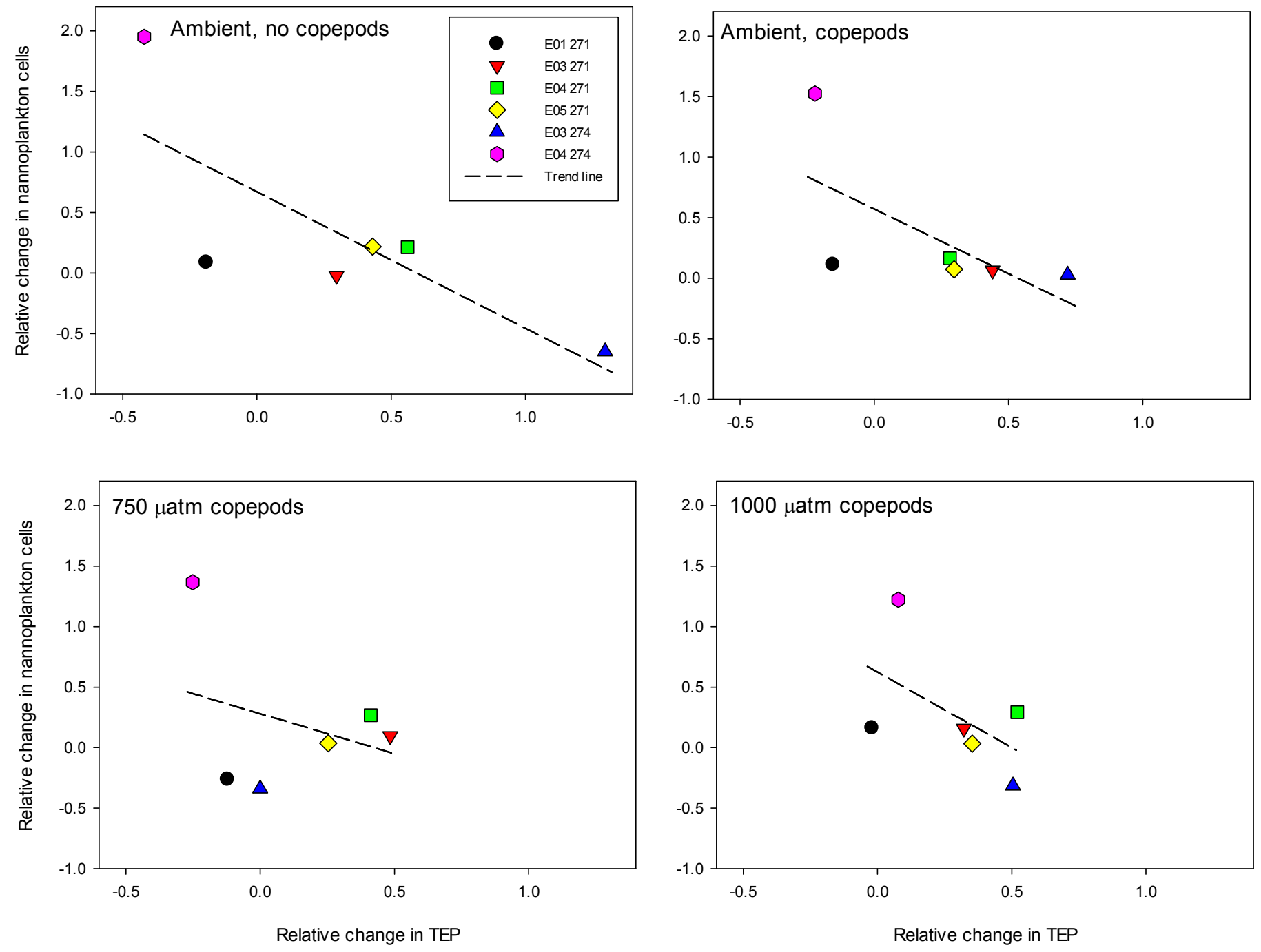

Fig. 6 

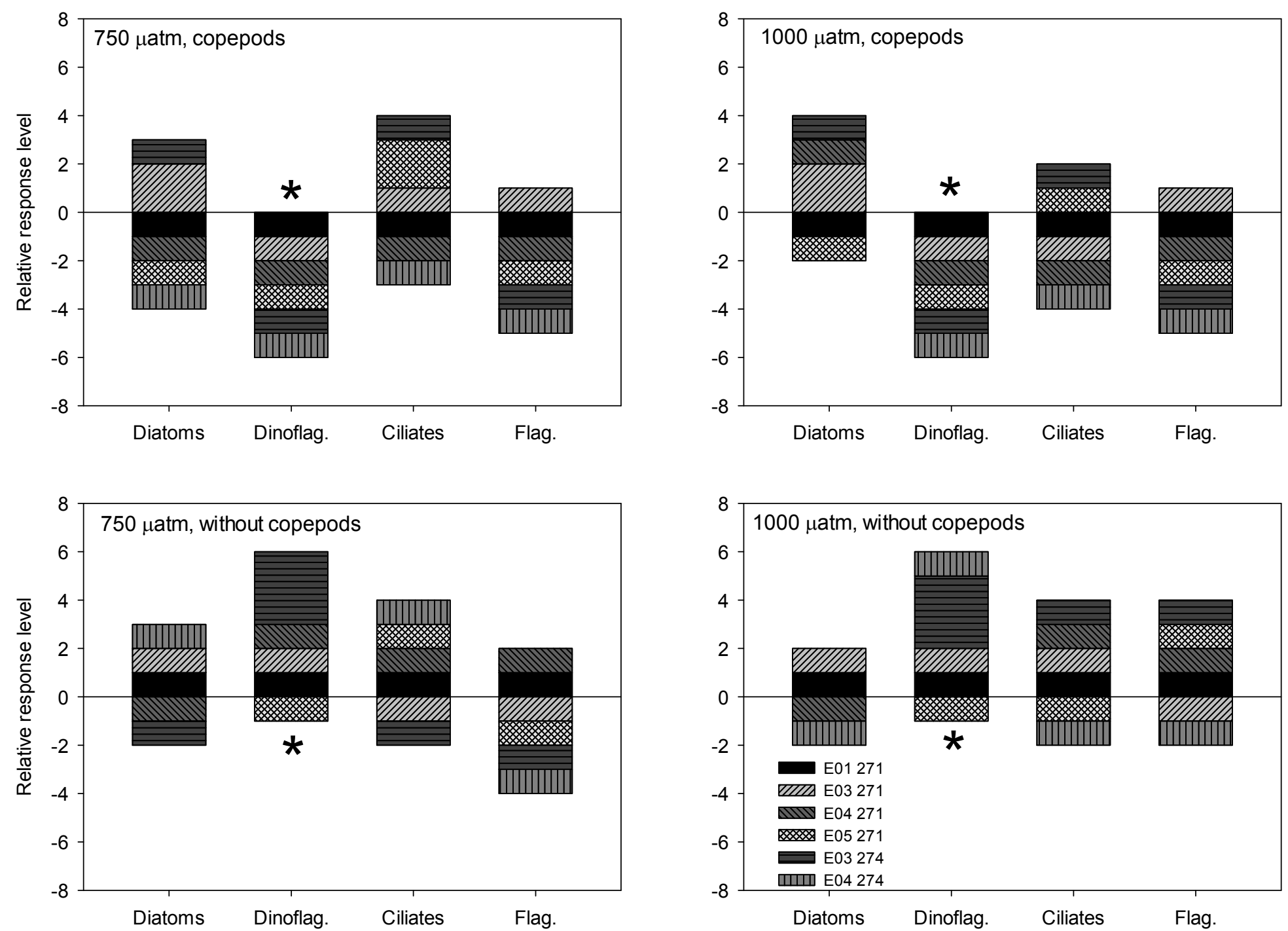

Fig. 7 

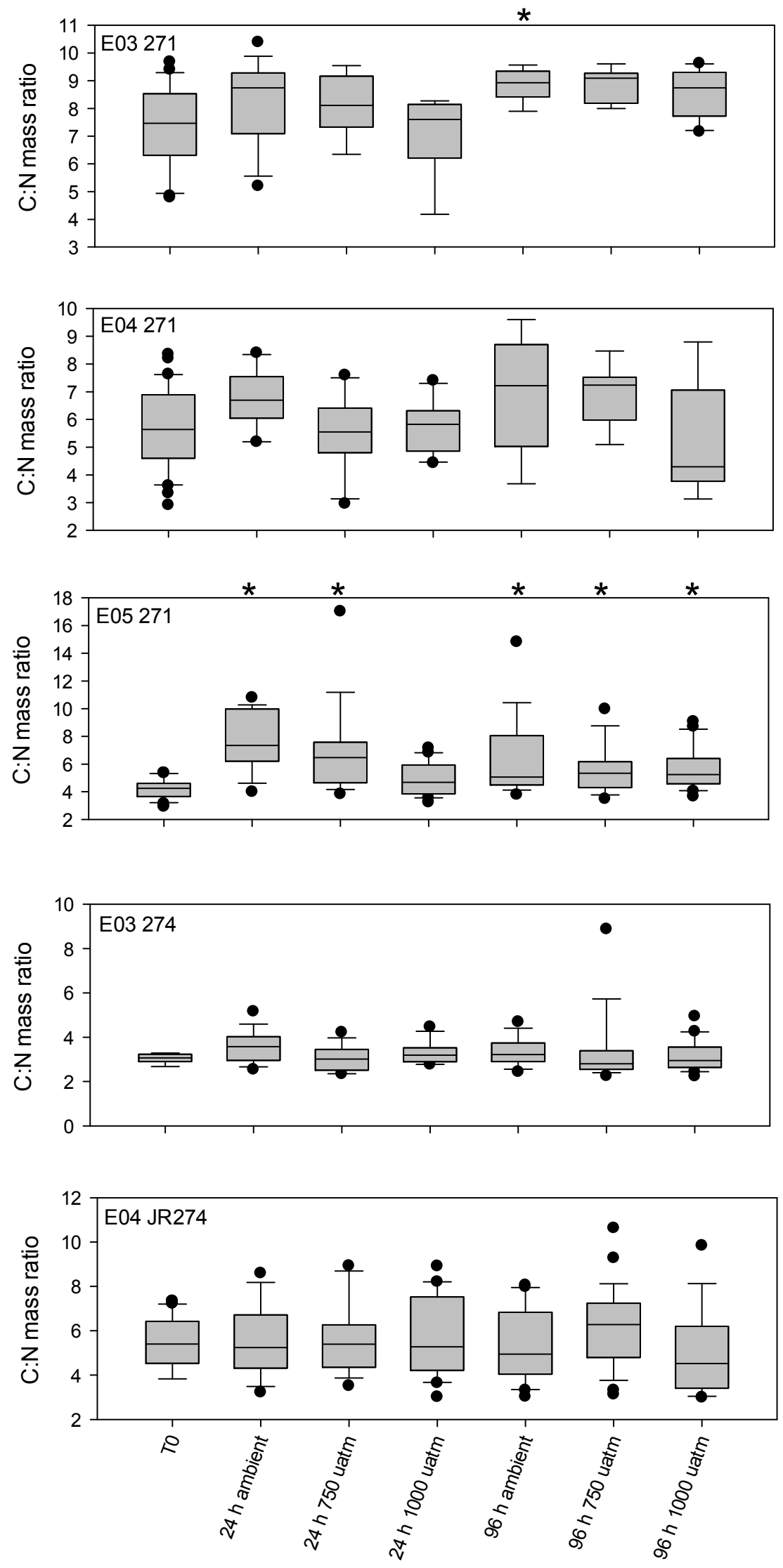

Fig. 8 